\title{
THE BIOLOGY OF CRANGON VULGARIS L. IN THE BRISTOL CHANNEL AND SEVERN ESTUARY ${ }^{1}$
}

\author{
By A. J. Lloyd, Ph.D., and C. M. Yonge, F.R.S. \\ From the Departments of Zoology, Universities of Bristol and Glasgow
}

(Text-figs. I-20)

\begin{tabular}{|c|c|c|c|c|c|c|c|c|c|c|c|c|}
\hline \multicolumn{13}{|c|}{ CONTENTS } \\
\hline Introduction & & & & . & . & . & . & . & . & . & . & 62 \\
\hline \multicolumn{5}{|c|}{ Collection and measurement. } & : & : & : & . & ${ }^{\circ}$ & & : & \\
\hline \multicolumn{5}{|c|}{ General description of the fisheries } & . & . & & & & & . & \\
\hline \multirow{2}{*}{\multicolumn{4}{|c|}{ The Estuary of the Severn }} & . & . & & & & & & $\therefore$ & \\
\hline & & & . & : & . & . & & & & & . & \\
\hline \multicolumn{2}{|c|}{ Conditions of life. } & . & . & . & . & . & & & & & . & \\
\hline \multicolumn{2}{|c|}{ Moulting and growth } & . & . & . & . & . & & & & & . & \\
\hline \multirow{2}{*}{\multicolumn{4}{|c|}{ Secondary sexual characters }} & . & . & . & & & & & . & \\
\hline & & & & & . & & & & & & . & \\
\hline \multicolumn{4}{|c|}{ Female reproductive organs } & & . & & & & & & . & 6 \\
\hline \multicolumn{6}{|c|}{ Development of the female pleopods. } & . & • & & & & . & \\
\hline \multicolumn{5}{|c|}{ Male reproductive organs. } & . & . & $\cdot$ & & & & . & \\
\hline \multicolumn{5}{|c|}{ Development of the male pleopods } & . & . & & & & & . & \\
\hline \multirow{2}{*}{\multicolumn{4}{|c|}{$\begin{array}{l}\text { Copulation } \\
\text { Spawning and egg-carriage }\end{array}$}} & . & . & . & & & . & & . & \\
\hline & & & & . & . & 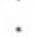 & . & & • & & . & \\
\hline \multicolumn{2}{|c|}{ Spawning seasons } & . & . & . & . & . & . & & - & & . & 64 \\
\hline Life history & & . & . & . & . & 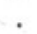 & . & & * & & & \\
\hline Migrations & . & . & . & . & . & . & • & & & & . & \\
\hline Sumn & . & . & . & . & . & . & . & . & $\cdot$ & & . & \\
\hline References & . & . & . & . & . & . & . & . & . & & . & \\
\hline
\end{tabular}

\section{INTRODUCTION}

This paper records observations on the biology of the common shrimp, Crangon vulgaris $\mathrm{L}$. The bulk of the work consisted of field observations and measurements, but supplementary evidence on such matters as food, habits, moulting, growth, mating, etc., was obtained in the laboratory and in aquarium tanks. All field work and measurements were carried out by one of us (A.J.L.) and the general direction of the research, analysis of some of the results and the preparation of this paper by the other (C.M.Y.). Acknowledgements for important assistance are due to $\mathrm{Mr} \mathrm{M}$. Haines of Berkeley, Mr R. Knapp of Oldbury, Mr Pullen of Severn Beach, Messrs Selwick and Brewer of Stolford, $\mathrm{Mr}$ Stone of Burnham-on-Sea and Messrs Watts of Weston, all of whom collected specimens. Mr McGurk, Bailiff to the Severn Fishery Board, kindly permitted one of us (A.J.L.) to accompany him on visits to the fisheries.

${ }^{1}$ Studies on the Biology of the Bristol Channel, No. I7. 
Various members of the Staff of the Department of Zoology, University of Bristol, assisted in measuring the shrimps, more than 28,000 of which were dealt with. The essential financial assistance was provided by the Leverhulme Trustees and by the Colston Research Society of the University of Bristol.

\section{Collection and Measurement}

Initially, in August 1937, the upper part of the southern shores of the Estuary of the Severn was surveyed; later, in December, Weston was included and in the following spring work was extended to Bridgwater Bay. The shrimps caught in one putt (see next section for a description of this) during one tide were placed in formalin, twice a week during I 938 and I939 and once a week in I940, by Mr R. Knapp of Oldbury on Severn (see Fig. I, station 2). The samples obtained from Bridgwater Bay (Stolford, station 6) were of ' unriddled' shrimps. These were taken monthly at spring tides and consisted of 500-1000 shrimps. Periodic visits were paid to the collecting areas so that catches could be examined. Temperatures and salinities were recorded. Maximum and minimum thermometers were maintained in the estuary at Berkeley (station I) and Oldbury (station 2) during 1938 and 1939. Temperature records from Weston were kindly supplied by the Medical Officer of Health.

All shrimps were measured and where possible (i.e. above $20 \mathrm{~mm}$. long) the sex determined. Measurement was from the tip of the rostrum to the end of the telson and carried out on a graduated glass plate illuminated from below. The exclusion of direct daylight by a board fixed along one side made accurate measurement easier.

\section{General Description of the Fisheries}

The Estuary of the Severn. This region possesses one of the largest recorded range of tides in the world. Extensive mud flats extend along the south bank of the Channel from Watchet to Berkeley (see Fig. I). Invertebrates living in this mud provide food for fish and shrimps. The higher reaches of the estuary are more sandy and rocky as the river is here confined by high banks and the strong current prevents the finer silt from settling. Since prehistoric times the local inhabitants have engaged in fishing. There are references in the Domesday Book to 72 places where 'fixed engines' were fished. The majority of these have long since disappeared and some of the few remaining are now falling into disuse. Those still fished usually fail to support the fishermen throughout the year.

Fish and shrimps are taken by means of nets and basket filters ("fixed engines') which are secured to stakes driven into the substratum of the foreshore. They are situated so that a strong tidal current flows through them and they are usually visited at each low tide by the fishermen although when the catches are poor the night tides are missed. An excellent general account of these fisheries is given by Matthews (1933). 


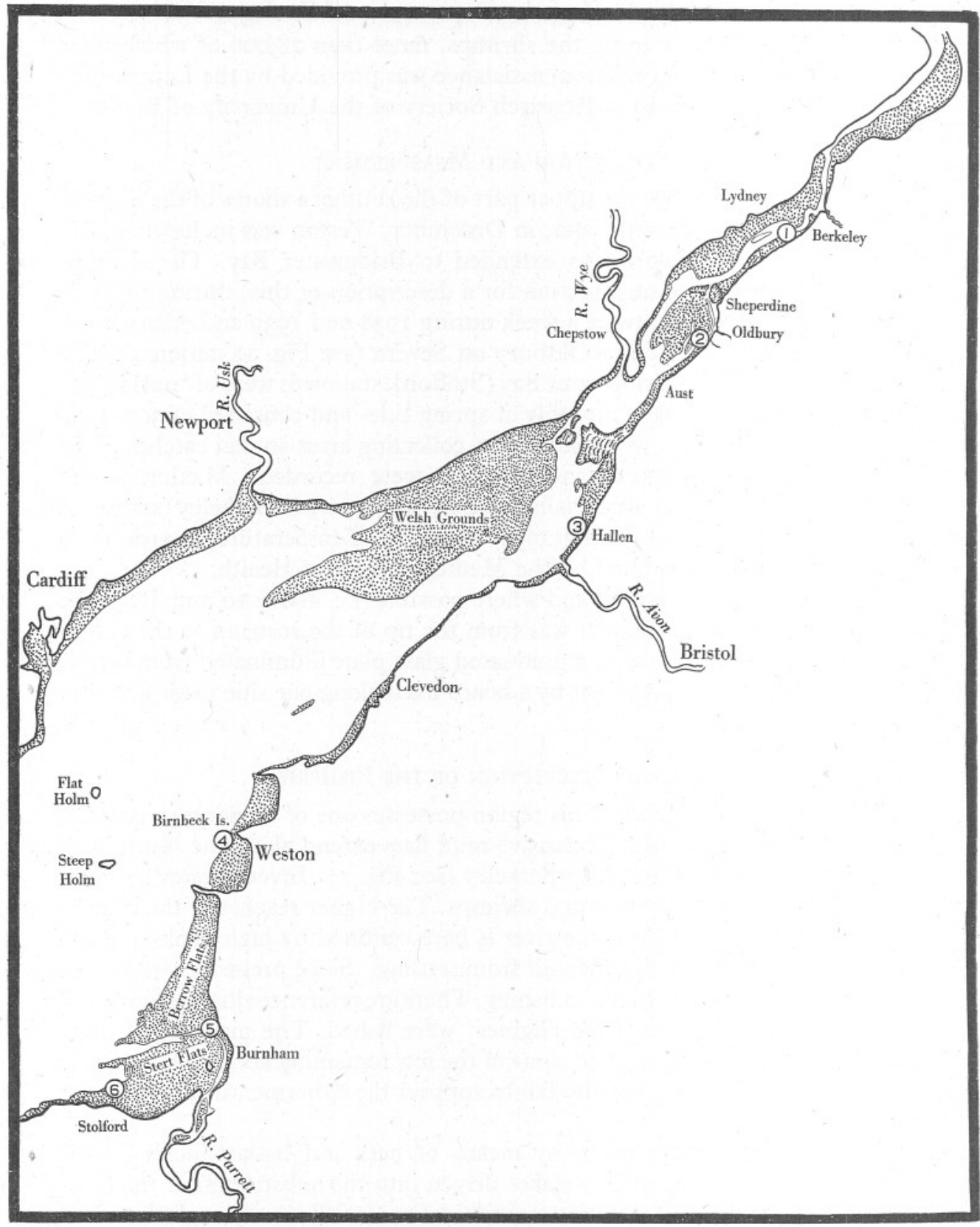

Fig. I. Map of the Severn Estuary and upper reaches of the Bristol Channel showing the positions of stations I-6. 
At the three collecting stations in the Severn ( $\mathrm{I}-3$ ) only baskets are in use. These are either putchers or putts, the former being used during the summer for trapping salmon while the putts are maintained throughout the year for catching shrimps and small fish. The putt is conical and up to $\mathrm{I} 5 \mathrm{ft}$. long with a diameter at the mouth of $5-7 \mathrm{ft}$. It consists of three parts. The front part is called the kype. The central part, or butt, contains a valve of split withies which retains the larger fish. The hindermost part is known as the forewheel, it also possesses a valve and is closed by a wooden bung. The kype is held in position between six stakes while the butt and forewheel are fixed in the cleft of two $\mathrm{Y}$-shaped stakes. The shrimps are removed by loosening the forewheel and removing the bung.

At Hayward Rock near Berkeley (station I) there is one of the best natural configurations in the estuary for basket fishing. The natural curve of the river bank opposite directs a very strong current inside Table Rock and over Hayward Rock. The Black Rock, about one mile higher up, tends to pull the water in towards the south bank and at the same time the sand banks on the north side push the current over. Both factors act as the tip of a funnel forcing the current to flow between Table Rock and the south bank. Hayward Rock tends to divert this back again to the main stream and an artificial hedge of withy and hazel helps to complete the funnel formation. Twenty putts are fished here.

An important fishery has existed since the fifteenth century at Oldbury (station 2), a plan of that date showing ranks of baskets in similar positions to those occupied now. The salmon pool is over two miles long. The baskets are placed where a strong subsidiary current drains the pool. Forty putts are staked in two ranks.

At Hallen (station 3) there was until recently a fishery consisting of 120 putts. Owing to the exposed situation, these were of stronger construction and of more open mesh work while the mouths were of smaller diameter.

The Bristol Channel. In this paper a necessarily arbitrary distinction is made between the Severn Estuary above Avonmouth and the Bristol Channel to the west of this port. At the three stations (4-6) in the Channel the hose type of shrimp net is used. The net is cone-shaped with a rectangular mouth of $5 \frac{1}{2} \mathrm{ft}$. long by $4 \mathrm{ft}$. high. Two circular hoops of cane hold the cod end open and there is a non-return valve of netting inside; a reeving rope draws together the meshes round the rear opening and passes to a stake behind. The belly of the net is of I in. mesh netting with $\frac{1}{2}$ in. mesh at the cod end. The mouth of the net is tied at the four corners to two stakes, one at each side.

There still exist three fisheries in the Bristol Channel. About 40 shrimp nets fish the ebb tide at Anchor Head, Weston-super-Mare (station 4). This fishery is not worked throughout the whole year. At Burnham-on-Sea (station 5) a rank of i 2 nets was maintained by an elderly fisherman; he has since died and the fishery has probably lapsed. Samples of shrimps were frequently 
taken from this fishery when they were unobtainable elsewhere. The largest shrimp fishery is at Stolford (station 6). Here about 400 nets are staked, but within living memory over 1000 were in use. A plan prepared in 1770 and in the possession of Lord Clifford shows over fifteen divisions of the Ooze with further subdivisions of fishing rights. The nets are more than a mile from the shore on the widely extended mud flats and the mud is so deep that peculiar sledges called 'mud horses' are pushed by the fishermen. These serve the double purpose of preventing the men from sinking far into the mud and of carrying the catch back to the shore. Many hundredweight of shrimps are taken daily in the summer.

\section{Conditions of LIFE}

Crangon vulgaris is specialized for life on a soft substratum of sand or mud. Havinga (1929) states that it rests quietly buried in the substratum during the day and feeds by night. This is certainly what happens in the aquarium but in the Bristol Channel and Estuary of the Severn there is no difference between the catches of the day and the night tides. Probably the exceptionally high turbidity of the water nullifies the effect of light. But the animals probably always rely on burrowing to escape from their enemies.

When placed in aquaria with sand on the bottom, shrimps remain buried during the daytime although the long flagellae of the second antennae may lie flat along the surface. These are used as tactile organs when seeking food. When burrowing the animal makes shuffling movements with the pereiopods, extending these slightly outward and backward, the pleopods at the same time beating rapidly. When a small hollow has been excavated, the animal alternately expands and contracts the branchiostegites thus forcing water out of the gill chambers and pushing the sand out and up around its sides. As a result the body sinks slowly down. Finally the flagellae of the antennae, with a breast stroke action, move sand around and over the back. The flagellae may also be withdrawn but the two small olfactory rami of the first pair of antennae always remain projecting vertically out of the sand and by their means food is detected. When walking along the surface the first three pairs of pereiopods are tucked away along each side of the mouth, the third pair, which project in front of it, being used as tactile organs. While swimming or walking, solid objects such as the walls of the aquarium, food and the like are tapped by the dactylopodites of these appendages. The last two pairs of pereiopods only are used for locomotion.

Although generally omnivorous, like most Decapoda, Crangon appears to prefer animal food. The mud flats it inhabits form a feeding ground for many small worms, molluscs and crustaceans. At Stolford a principal food appears to be Nereis diversicolor and shrimps have often been caught while eating worms longer than themselves. In the spring the thorax sometimes appears bright green due to ingested algae. This condition occurs locally and 
shrimps taken two miles away may contain no algae. Ehrenbaum (I890) states that shrimps feed mainly on polychaetes, especially $N$. pelagica, and Havinga (I929) agrees with this. He also includes in their food, Ulva lactuca and Enteromorpha intestinalis and, in brackish water, Corophium sp., Gammarus locusta and Mysis vulgaris. These animals occur in the Channel and estuary and, together with small gastropods, bivalves, fish eggs and fry, form the food of Crangon.

The animal can withstand a wide range of temperature. The winter migration down channel, especially from the estuary, is, as shown below, due to inability to withstand low salinity combined with low temperature. Under aquarium conditions shrimps have survived after ice has formed over the surface of the undiluted sea water. Havinga (1930) states that Crangon can survive shore temperatures as high as $30^{\circ} \mathrm{C}$. In the estuary at Oldbury, maximum numbers appeared after the temperature exceeded $10^{\circ} \mathrm{C}$., reduction in numbers during June and July being a result of migration of berried females seaward before hatching of the larvae. At Stolford, in the Channel, the largest numbers were caught during July and August when temperatures rose as high as $20^{\circ} \mathrm{C}$.

Crangon is euryhaline; Mathias (1938) found that death occurs after exposure to freshwater for $7-8 \mathrm{hr}$. but that animals (sex unstated) survive exposure for more than a day to sea water diluted by 255 times its volume of freshwater. The capacity to withstand low salinities is influenced by temperature, especially in connexion with development, as noted by Balss (I930) for a wide variety of decapod Crustacea, by Otto (1934, 1937) for Heteropanope and Eriocheir, by Broekhuysen (1936) who made a special study of the shore crab, Carcinides maenas, and later by Panikkar (1940, I94I) for Leander serratus and Palaemonetes varians. Caudri (1937) extended Broekhuysen's observations to Crangon and found that at a temperature of about $4^{\circ} \mathrm{C}$. the optimum salinity for survival of young shrimps was $34^{\circ} \%$ whereas at $18.9^{\circ} \mathrm{C}$. lowest mortality was between 20 and $30 \%$. Broekema (194I), in a paper not seen until after the first draft of this paper was completed, has extended these findings greatly as a result of work prompted by the observations of Havinga (1930) on the seasonal migrations of Crangon in the Zuiderzee (prior to the closure of this by the dyke). She has confirmed Caudri's statement that the salinity optimum shifts downward with increasing temperature. For animals two years old it lies at $35^{\circ} \%$ for a temperature of $3.5^{\circ} \mathrm{C}$. and at $28-29 \%$ for temperatures between 20 and $22^{\circ} \mathrm{C}$. For animals about one year old it lies at I8-19\% for a temperature of $22{ }^{\circ} \mathrm{C}$., the optimum salinity apparently moving higher with increasing age. The salinity range for normal development was also influenced by temperature as Broekhuysen (1936) had already found for Carcinides.

Broekema also found that Crangon is to some extent homoiosmotic although changes in the osmotic pressure of the medium were reflected by smaller 
changes in that of the body fluids, i.e. resembling Leander serratus and $L$. squilla (Panikkar, 194I). Like Leander spp., in normal sea water Crangon is hypotonic in respect to the medium, being isotonic with it at a salinity of about $2 \mathrm{I} .5 \%$ at $20{ }^{\circ} \mathrm{C}$. and at a salinity of about $23 \%$ at $4{ }^{\circ} \mathrm{C}$. Experimental evidence indicated, moreover, that osmo-regulation proceeds more efficiently at high temperatures and indeed may be largely inhibited at low temperatures. This may provide the explanation of the inability of Crangon (and similar Decapoda) to withstand exposure to low salinities during the winter.

Although Broekema made certain observations on ovigerous females, no mention of the sex of the animals used in other experiments is made and they were presumably mixed. But as noted by Havinga (1930) and abundantly confirmed in this work (see Table IV), there is a marked difference between the sexes in their toleration of low salinities. The males are largely or completely absent fom the upper reaches of the Severn Estuary during the winter. This difference led to the carrying out of initial experiments on the effect of salinity on respiration in the two sexes. It was hoped in this way to get some indication of possible differences in the capacity for osmo-regulation in the two sexes.

Pure sea water, salinity c. $34 \%$, was diluted with glass distilled water and complete aeration ensured. Experiments were conducted in conical flasks containing 500 c.c. of water containing $0.5 \%$ urethane. The animals were kept in water of the same salinity overnight to allow time for physiological adjustment and were anaesthetized with urethane $30 \mathrm{~min}$. before the experiment began. Each experiment lasted $4 \mathrm{hr}$., the temperature being maintained always at $15^{\circ} \mathrm{C}$. The oxygen content of the water was estimated before and after each experiment and the results converted into oxygen consumed per gram wet weight per hr.

The results are shown in Fig. 2. The females showed a higher respiratory rate down to $35 \%$ normal salinity, below that it was higher in the males. These died at salinities below ro \% but females actually survived exposure to fresh pond water for several days. The lowest respiratory rate for the males was in water of $50-60 \%$ normal salinity and for females $25 \%$. Oxygen consumption increased only moderately in higher salinities but rapidly in lower salinities, that for the males rising to 2.09 c.c. oxygen per hr. at I0 \% salinity. While too much weight cannot be placed on these preliminary experiments (circumstances prevented their continuation), they do at least confirm the conclusions derived from field observations, namely that males cannot withstand such low salinities as females and that optimal salinity, at a temperature of $15^{\circ} \mathrm{C}$., is higher for males than females. The powers of osmo-regulation in the male are not as great as in the female.

There is evidence from various sources of the effect of light on Crangon. Thus Havinga (1930) records that the animals remain swimming within a beam from an artificial source of light and so are easily caught. Plankemann (I935) found that light of short wave-length speeds up moulting, while Nouvel- 
Van Rysselberge (1937) states that exposure during successive nights to artificial light has the opposite effect of delaying moulting. In the exceptionally turbid waters of the estuary and Channel it is very doubtful whether the small amount of light that can penetrate has any significant effect on the behaviour or metabolism of the shrimps.

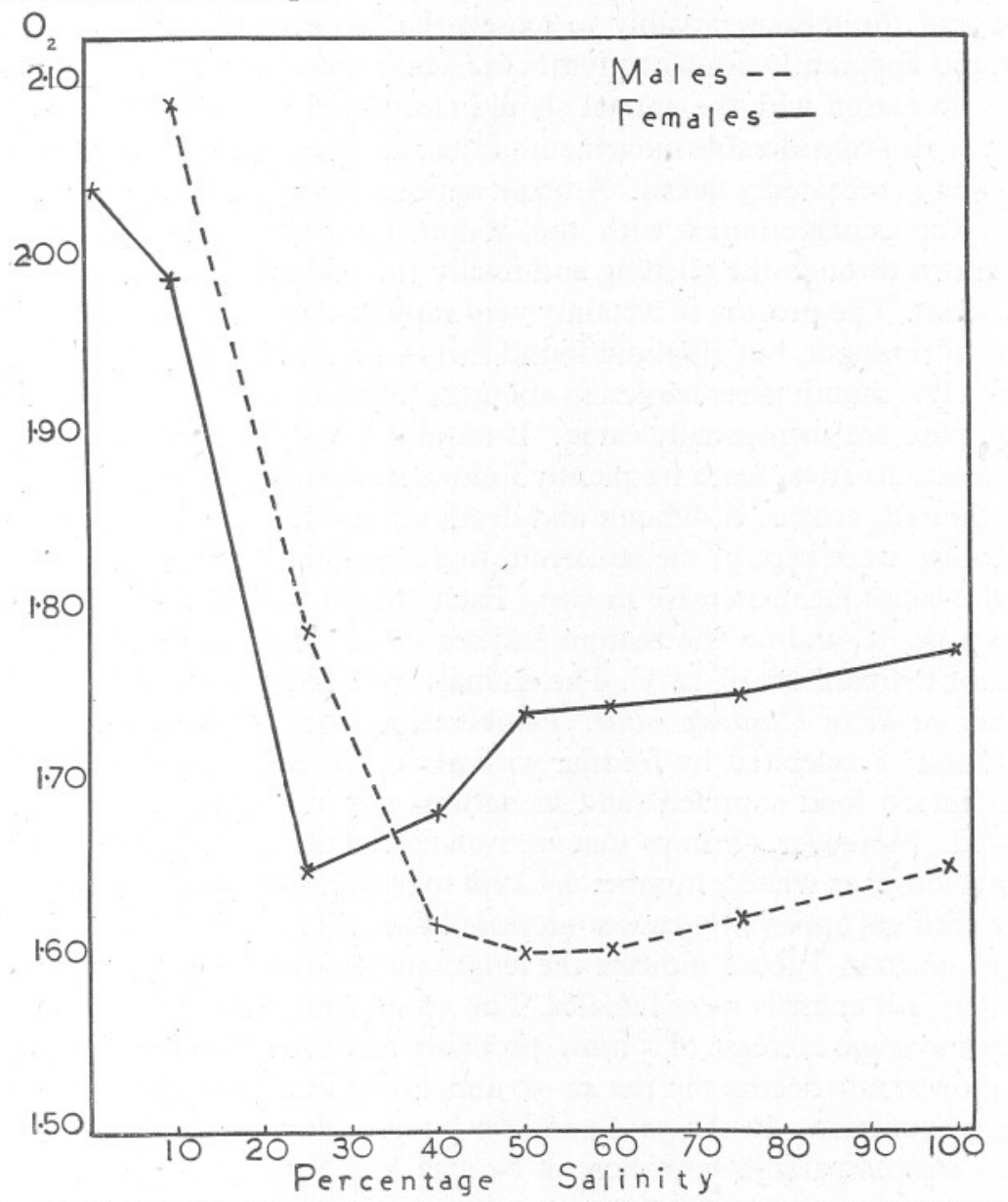

Fig. 2. Graph showing the effect on respiration of exposure of male and female Crangon vulgaris to varying salinities at $15^{\circ} \mathrm{C}$. Figures for oxygen given in c.c. utilized per hr. per gram wet weight of animal; salinity in percentages of normal sea water.

\section{MOULTING AND GROWTH}

Crangon becomes more opalescent immediately before moulting; Vitzou (I882) noted a similar change in Leander. This is probably due to the formation of the new integument beneath the old one. Food is not eaten during two or three days prior to ecdysis which usually occurs at night. Höglund. (I943) has 
observed a similar period of starvation in L. squilla but finds that moulting may occur at any time throughout day or night. This difference may well be correlated with the different habits of the two animals, Crangon normally leaving the protection of the substratum only in darkness. During this preliminary period the chelipeds stroke the peduncules of the eyes, the antennal scales and the telson, possibly to loosen the integument although Höglund interprets apparently similar activities in Leander squilla as cleansing. But there seems no reason why the animal should cleanse what is about to be cast off. There is also considerable movement of the antennae and antennules while the abdomen is repeatedly flexed. A break appears at the intercalary piece which unites the cephalothorax with the abdomen. The head and thorax are withdrawn through the opening and finally the abdomen is freed by a quick movement. The process is certainly very rapid although there was no opportunity of timing it, but Höglund found that in L. squilla it takes only from 9 to $22 \mathrm{sec}$. The mouth parts harden in about $24 \mathrm{hr}$. and the softer parts of the cast integument are then usually eaten. If moulting has been preceded by a long period of starvation death frequently follows its occurrence. If the animal has been injured, ecdysis is difficult and death often follows.

Shrimps were kept in the aquarium to determine the frequency of ecdysis and the consequent increase in size. Each animal was placed in a tank with about $\frac{1}{2}$ in. of sand on the bottom and sea water was kept in circulation at a constant temperature of $12^{\circ} \mathrm{C}$. The animals were fed daily with the tissues of Mytilus edulis or Cardium edule. Plankemann (1935) found that the rate of moulting is accelerated by feeding with glycogen, but as the content of this varies in the food supplied (and in nature) the influence of this cannot be assessed. Moreover, shrimps that are isolated, as these had to be, do not feed as voraciously as when a number are kept together; the constant movement of many shrimps apparently causes increased feeding in all.

Data given in Table I indicate the length increase after moulting during the summer. All animals were females. The $30-40 \mathrm{~mm}$. length group shows the greatest average increase of $3 \mathrm{~mm}$., probably because they are still immature. The growth rate declines in the $40-50 \mathrm{~mm}$. group as more material is deflected to egg production. In the $50-60$ and $60-70 \mathrm{~mm}$. groups it is still less. These figures are comparable with those of Nouvel-Van Rysselberge (1937), namely $2 \cdot 0-2.5 \mathrm{~mm}$. increase at $30-40 \mathrm{~mm}$., $2.5-2.0 \mathrm{~mm}$. at $40-50 \mathrm{~mm}$. and I. $5-\mathrm{I} \cdot 0 \mathrm{~mm}$. at 50-60 $\mathrm{mm}$. lengths. This work was done during the summer at Monaco and the shrimps moulted every IO-I2 days. Personal observations showed that at I $2^{\circ} \mathrm{C}$. shrimps moult at much longer intervals, I3-30 days or even more. There is much variation in both length increase and the duration of the intermoult period due, probably, to fluctuations in environmental factors. Nouvel-Van Rysselberge has shown that the rate of growth is less under aquarium conditions than in nature.

Females above $50 \mathrm{~mm}$. long normally carry eggs during the spring and 
summer. There is no increase in length at the moult into the egg-laying condition. Possibly the demands of the ovary are largely responsible for this but there are also greater demands for chitin for the egg-carrying setae which now appear. Plankemann (1935) has shown that there is a steep rise in the curve of chitin formation during June and this may well be associated with the additional needs for chitin during the period of egg-carriage.

After hatching of the larvae the females normally pass into a resting, 'neuter' condition with the usual increase in length. But occasionally they may pass

\section{Table I. Increase in Length of Female CRANGON VULGaris after Initial Moult in Aquarium}

\begin{tabular}{|c|c|c|c|c|c|}
\hline $\begin{array}{l}\text { Initial length } \\
\text { (mm.) }\end{array}$ & $\begin{array}{l}\text { New length } \\
\text { (mm.) }\end{array}$ & $\begin{array}{c}\text { Increase } \\
(\mathrm{mm} .)\end{array}$ & $\begin{array}{c}\text { Initial length } \\
\text { (mm.) }\end{array}$ & $\begin{array}{c}\text { New length } \\
(\mathrm{mm} .)\end{array}$ & $\begin{array}{c}\text { Increase } \\
(\mathrm{mm} .)\end{array}$ \\
\hline 36 & 39 & 4 & 45 & 48 & 3 \\
\hline 32 & 36 & 4 & $4 \mathrm{I}$ & 45 & 3 \\
\hline 37 & 40 & 3 & 44 & 47 & 3 \\
\hline 37 & 39 & 2 & 42 & 44 & 2 \\
\hline 39 & 42 & 3 & 44 & 47 & 3 \\
\hline 37 & 40 & 3 & 42 & 44 & 2 \\
\hline $3 \mathrm{I}$ & 34 & 3 & 48 & $5 \mathrm{I}$ & 3 \\
\hline 30 & 33 & 3 & 44 & 46 & 2 \\
\hline 32 & 35 & 3 & 47 & 50 & 3 \\
\hline 33 & 35 & 2 & 44 & 46 & 2 \\
\hline \multicolumn{5}{|c|}{ Average increase: $3 \mathrm{~mm}$. } & $2.6 \mathrm{~mm}$. \\
\hline 56 & 58 & 2 & 60 & 62 & 2 \\
\hline 50 & 52 & 2 & 63 & 65 & 2 \\
\hline 54 & 56 & 2 & $6 \mathrm{I}$ & 62 & I \\
\hline 52 & 55 & 3 & 63 & 64 & I \\
\hline 53 & 56 & 3 & 64 & 65 & I \\
\hline 55 & 57 & 2 & 65 & 66 & 2 \\
\hline 58 & 60 & 2 & 67 & 68 & I \\
\hline 53 & 55 & 2 & 68 & 69 & I \\
\hline 52 & 54 & 2 & 63 & 65 & 2 \\
\hline $5 \mathrm{I}$ & 53 & 2 & - & - & - \\
\hline \multicolumn{5}{|c|}{ Average increase: $2.2 \mathrm{~mm}$. } & $\mathrm{r} \cdot 3 \mathrm{~mm}$. \\
\hline
\end{tabular}

directly into a second period of egg-carriage and do not increase in size. The duration of the egg-carrying intermoult is longer than normal, approximately 35 days at $12^{\circ} \mathrm{C}$.

H. \& L. Nouvel (1937) found that, out of a number of Caridea studied, failure to copulate does not prevent subsequent spawning except in Athanas nitescens, but that the unfertilized eggs are lost. This is also true for Leander squilla (Höglund, 1943) and for Crangon. But whereas these workers state that the length of the intermoult is not reduced when eggs are lost, in Crangon it did appear that the intermoult periods were the same length as for 'neuter' females, namely between $\mathrm{I} 3$ and 30 instead of 35 days. But there was such a wide variation in the length of intermoult periods in Crangon that too much weight cannot be put on these findings.

During the winter, observations similar to those recorded above were carried out at atmospheric temperatures. The intermoult period was $60-70$ days with 
little or no length increase. Plankemann (1935) states that there is no moulting between November and March, while Höglund (1943) found moulting at long intervals during the winter in Leander squilla but no growth. As shown in Fig. I5, there is little difference in the size distribution of shrimps taken from the Bristol Channel throughout the winter months.

Under natural conditions there is little doubt that, as already suggested by Nouvel-Van Rysselberge, growth is greater than that recorded in the aquarium (Table I). Reference to Fig. I5 shows an increase in length of young females from around $35 \mathrm{~mm}$. to around $45 \mathrm{~mm}$. between June and July, probably as a result of two moults (see p. 652). This possible length increase of $5 \mathrm{~mm}$. (at this size) in successive moults is, at first sight, borne out by a more or less regular appearance of peaks at $5 \mathrm{~mm}$. intervals in many of the graphs. But it has been pointed out by Mr. G. M. Spooner that, in certain sets of data, an artificial bias must exist which gives peaks at the major scale divisions, i.e. at whole $5 \mathrm{~mm}$. intervals (at the expense of adjacent points). The effect, he explains, clearly shows for the total 1939 catches in Fig. I8; and it is questioned whether the pronounced peaks in Fig. Io (March-June), Fig. I6, and Fig 20 have any real significance: for any natural periodicity which these graphs could have brought out will have been largely obscured or exaggerated. Owing to the separation of the two authors and their preoccupation with other work, it has been impossible to correct this bias, which does not affect general conclusions drawn from these graphs.

\section{REPRODUCTION}

Secondary sexual characters. There are marked external differences between the sexes. In the male the external (olfactory) branch of the first antenna is larger, possessing, in an animal $72 \mathrm{~mm}$. long, 20 more segments than in a female of the same length. The basal joint of the second antenna bears a long flagellum which is the same length as the body in the female but longer than this in the male. Although, as in all Decapoda, the genital openings are in different positions in the two sexes, these can only be easily seen in animals about to spawn.

In animals $20 \mathrm{~mm}$ : long and under, the endopodite of the first pleopod is of similar size in both sexes, but in the males it is bent in a hooked position over the joint between the basipodite and the exopodite. It is so small as to be barely visible to the naked eye. In females over $25 \mathrm{~mm}$. this endopodite is relatively long and lies parallel to the exopodite whereas in the male it is too small to be seen by the naked eye. The endopodite of the second pleopod is biramous in the males. The inner branch or appendix masculina is spinous on one side while the outer branch resembles the unbranched endopodite of the female and is similarly clothed with long, plumose setae (Fig. 8).

The females live longer and grow larger than the males. Females have been 
obtained up to $85 \mathrm{~mm}$. long from tip of antennal scale to the end of the telson; the largest male was $72 \mathrm{~mm}$. long, but few exceed $60 \mathrm{~mm}$.

Female reproductive organs. The female usually becomes mature during the second year. There is a gradual preparation for the carriage of eggs. The endopodite of the first pleopod grows rapidly in comparison with the rest of the limb and there is a slow increase in the ovary with a sudden development during the spring of the second year.

The paired ovaries are united anteriorly and again in the region in front of the junction of the abdomen and thorax. They extend from the dorsal surface of the gizzard ('cardiac' stomach) to the third abdominal segment. The details of internal structure are essentially as described by Herrick (I9II) for Homarus americanus.

Growth in each ovary is slow up to a body length of about $40 \mathrm{~mm}$. (Fig. 3A), but increases greatly with the approach of egg laying in the summer of the second year (Fig. 3B). Immediately preceding spawning the eggs can be seen through the integument as a whitish translucent mass in the greatly distended ovaries. After spawning the ovary is reduced to about one-tenth of its former mass (Fig. 3 C), but during the summer new eggs are rapidly formed and by the end of the period of egg-carriage the ovary may have regained half its former size. After the last spawning of the season, however, there is little ovarian activity and the animal passes into the winter resting condition with the ovaries only slightly exceeding their minimum size (Fig. 3D). Spawning may next take place as early as January or February, but there is a quiescent period during October and November when no egg-carrying females are found.

The oviducts leave the ovaries about one-quarter of their length from the anterior end. In immature females the epithelium is only $\mathrm{I} \cdot 3 \mu$ thick, but before spawning this increases to $3 \mu$ and the

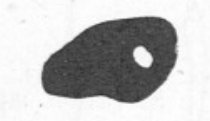

A

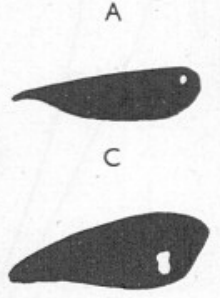

D

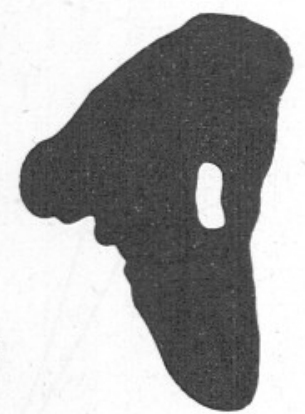

B

Fig. 3. Crangon vulgaris, comparative cross-sectional areas of left ovaries from: A, immature virgin shrimp, $37 \mathrm{~mm}$. long (May); $\mathrm{B}$, ripe virgin shrimp, $55 \mathrm{~mm}$. long (June); C, eggcarrying shrimp, $60 \mathrm{~mm}$. long (July); $\mathrm{D}$, resting shrimp, $60 \mathrm{~mm}$. long (October). Region occupied by primordial ova shown white, by ripening ova shown black. cells become glandular. There is a slow return to the original condition after spawning. Yonge (1937) has shown that in Homarus vulgaris the oviduct secretes the inner, chitinous membrane around the egg. Conditions in Crangon are similar.

Development of the female pleopods. The pleopods undergo considerable changes during development. At a body length of $\mathrm{I} 6 \mathrm{~mm}$. the endopodite of the first pleopod is very small (Fig. 4A), but then begins to increase relatively to the 
rest of the appendage and to move away from the exopodite. In animals $46 \mathrm{~mm}$. long five spur-like projections appear on its inner side and two series of spurs arise on the basipodite (Fig. $4 \mathrm{~B}, s p$ ). As the maturity is approached, at a length of about $50 \mathrm{~mm}$., a number of curved 'raking' setae appear at the end of the endopodite (Fig. $4 \mathrm{C}, r s$ ). The function of these is a little uncertain; although non-plumose they are not concerned with egg-carriage. At the same time the spurs increase in size and others appear on the basipodites of the second and third pairs of pleopods, but only the basal series on the fourth pair. Sollaud (1922) termed such structures 'caractères sexuels secondaires tardifs' and they are characteristic of the 'neuter' condition. No spurs appear on the fifth pair of pleopods which never carry eggs.

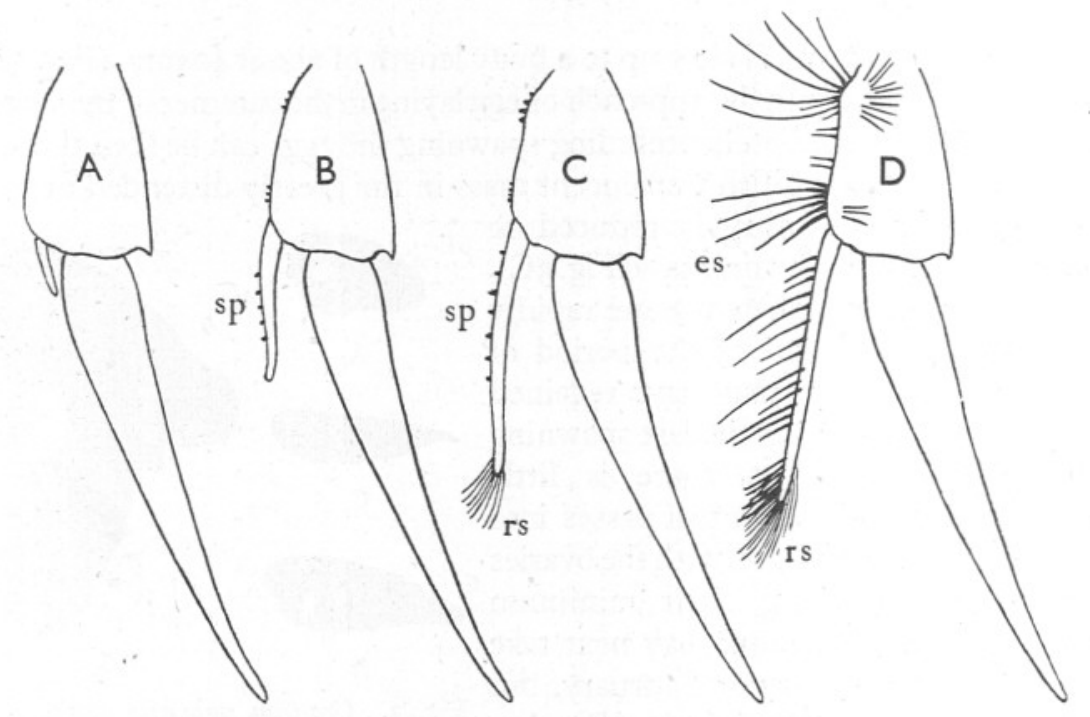

Fig. 4. Crangon vulgaris, outline sketches of first pleopod of female in animals of length: A, $16 \mathrm{~mm}$.; B, $46 \mathrm{~mm}$.; C, $50 \mathrm{~mm}$.; D, $50 \mathrm{~mm}$. All drawn the same size to emphasize the relative increase in size of the endopodite. es, egg-carrying setae; $s p$, spurs representing precursors of egg-carrying setae; $r s$, 'raking' setae. Plumose setae not shown.

When sexually mature the female moults into the egg-carrying condition. There is an increase of about one-tenth in the width of the abdomen and the pleura become somewhat larger. Since these observations were made, Höglund (1943) has described in detail similar changes in Leander squilla. Long non-plumose egg-carrying setae (Fig. ${ }_{4} \mathrm{D}, e s$ ) replace the spur-like projections previously present while additional shorter egg-carrying setae appear close to these. Similar setae also appear on the coxopodites of the last two pairs of thoracic legs. The appearance of the first two thoracic appendages and the pleopods in the 'neuter' intermoult is contrasted in Fig. 5 with their condition in the spawning intermoult when the eggs become attached. There 
is also an increase in the size and number of the plumose setae on all the pleopods, on the margin of the pleura, around the genital openings and especially along two sides of the long endopodite of the first pleopod. These setae protect the egg mass, laterally and ventrally, and, by their movements, create respiratory currents. A detailed account of the modifications associated with egg-carriage in Crangon will be included in a general paper dealing with such modifications throughout the Caridea which is being prepared by one of us (C.M.Y.).
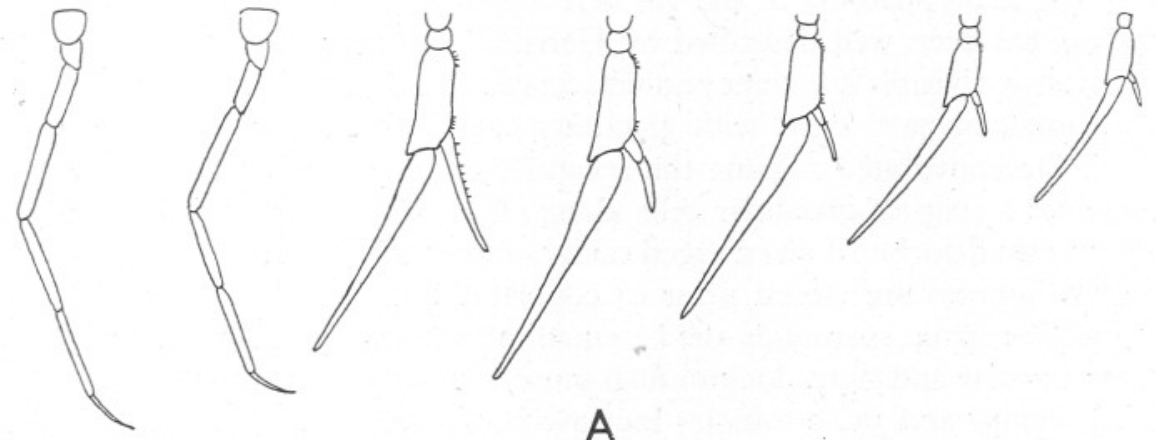

A

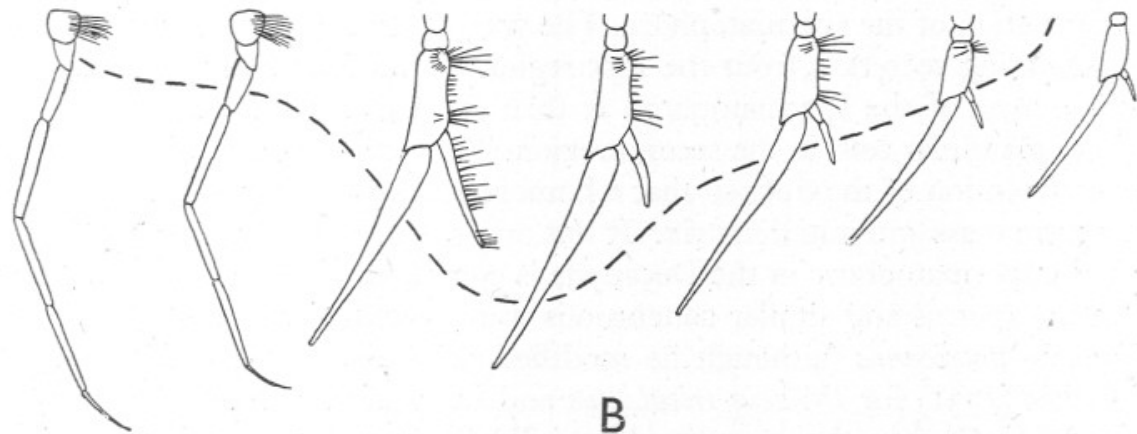

Fig. 5. Crangon vulgaris, semi-diagrammatic representation of the last two pereiopods and all pleopods of one side in: A, female in the intermoult preceding egg-carriage; $\mathrm{B}$, in the eggcarrying intermoult. The egg-carrying setae and their spur-like precursors are shown but not the 'raking' setae nor any of the plumose setae. The area occupied by the egg mass is indicated by the broken line.

In the decapod Crustacea the eggs are secured to the appendages by cement secreted by contained tegumental glands as described by Yonge (1937) in Homarus vulgaris. In Crangon the intimate association of the glands with the egg-carrying setae is clearly demonstrated by the reduction of both during the 'neuter' periods between successive sexual intermoults. The glands are greatly reduced and the setae revert to the spurs already described. This alternation continues throughout the remainder of the life of the female as briefly recorded elsewhere (Lloyd \& Yonge, I940). 
Male reproductive organs. The testes are situated in the same region as the ovaries and are also united anteriorly and centrally. They become very active when the males attain lengths of about $40 \mathrm{~mm}$. when all stages in the maturation of spermatozoa are present and ripe spermatozoa occur in the vasa deferentia. These leave the centre of the testes laterally. The proximal portion is convoluted but the distal part passes direct to the opening on the base of the last pereiopod. Striated muscle is abundant near the opening and the contraction of this assists in the expulsion of the spermatophores.

The general anatomy of the vas deferens and the function of the various regions has been well described by Herrick (I9II) for Homarus americanus. The duct is divisible into three regions according to the nature of the epithelium. The proximal part, lined with glandular cells, extends for a short distance down the convoluted region; the second part, which is much the longest, possesses a strip of glandular cells along one side only; the third region, or ductus ejaculatorius, is an enlarged cavity, devoid of glandular cells, where the spermatophores are stored prior to copulation. Only a thin layer of elastic connective tissue surrounds the basement membrane in the first region, but inner circular and outer longitudinal muscle layers surround the second and third regions and these muscles increase in thickness towards the opening.

The secretion of the glandular region of the vas deferens is concerned with the formation of the spermatophore. The sperms are apparently embedded in a coagulating secretion from the first region of the duct and the outer protective layer of the spermatophore is then formed around the mass by the strip of glandular cells in the second region. This strip forms a spiral owing to the convolution of the duct so that a homogeneous layer is laid down around the sperm mass and initial matrix. It was originally shown by Grobben (1878) that the spermatophore in the Decapoda is composed of two substances apart from the sperms and similar conclusions were reached by Herrick (I894) for Homarus americanus (although he modified this somewhat later (I9II)), by Mouchet (I93I) for Penaeus trisulcatus and by Spalding (1942) for Carcinus maenas. In Crangon the spermatophore is finally extruded as a thin strand-like vermicelli containing masses of sperms at irregular intervals.

Development of the male pleopods. As noted above, the endopodite of the first pleopod is minute and bent in small males (Fig. 6A). At a body length of $35 \mathrm{~mm}$. it has lengthened and possesses three hooked and two straight spines (Fig. 6B). Finally, at sexual maturity, it is bent more acutely (Fig. 6C) and bears twelve hooks and eighteen spines along the outer side (Fig. 7). At this stage the appendix masculina has fully developed on the endopodite of the second pleopod (Fig. 8); it possesses eighteen strong spines along the side and end of the ramus. As noted by Nouvel (1939), it is late in developing and at a length of $35 \mathrm{~mm}$. the ramus has only three or four spines.

Copulation. The process of copulation in Crangon has been described by Nouvel (1939) and is essentially similar to that in other Caridea such as Athanas 
nitescens, Leander squilla and Alphaeus dentipes (H. \& L. Nouvel, 1935, 1937). The process was observed by placing a male in an aquarium tank containing a female which had just moulted from the 'neuter' to the egg-carrying condition. After certain preliminary behaviour, described by Nouvel, the male turned the now passive female on to her back and then bent his body in a $U$-shape transversely across that of the female about the junction of the thorax and abdomen, so that the ventral regions of the two animals were in contact.
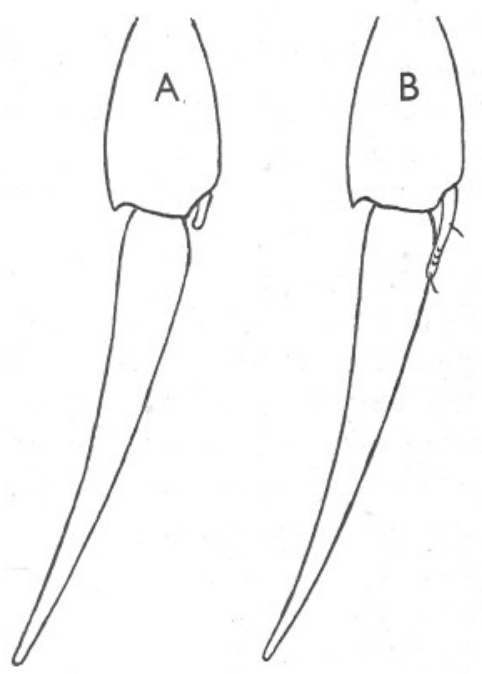

Fig. 6.

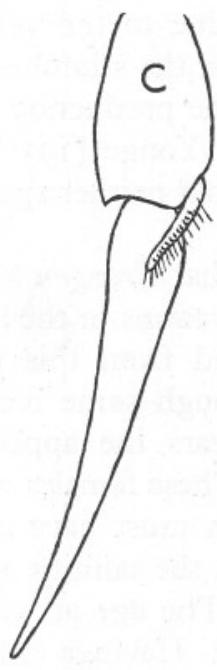

Fig. 7 .

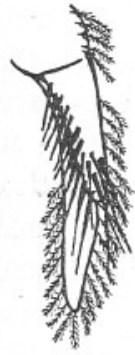

Fig. 8 .

Fig. 6. Crangon vulgaris, outline sketches of first pleopod of male in animals of length: A, Io mm.; B, $35 \mathrm{~mm}$; C, $57 \mathrm{~mm}$. All drawn the same size to show relative increase in size and change in form of the endopodite.

Fig. 7. Crangon vulgaris, endopodite of first pleopod of male $57 \mathrm{~mm}$. long enlarged to show hooks and spines.

Fig. 8. Crangon vulgaris, endopodite of second pleopod of male $72 \mathrm{~mm}$. long showing appendix masculina (inner ramus).

Nouvel describes the male as sliding his body under that of the female. The male does not apparently grasp the female by any of his appendages and, despite the contrary statements of Havinga (1929), there are no copulatory organs, the spermatophores being applied to the ventral side of the female usually more or less adjacent to the genital opening. Contact was maintained for about five seconds after which the animals fell apart, motionless. The female recovered first and after a few minutes buried herself in the sand. Throughout, the still soft-shelled female is apathetic, as noted by Nouvel, and does not seek copulation. The male alone shows activity and is ready to copulate again within a few minutes. Nouvel states that the females sometimes permit 
a second copulation, but this was not personally observed. Nouvel also records the copulation of large females, up to a length of $58 \mathrm{~mm}$., with males of from 30 to $36 \mathrm{~mm}$.

Eggs are laid within two days of moulting into the egg-carrying condition, irrespective of copulation as already stated. If copulation has occurred, spawning normally follows within $24 \mathrm{hr}$. Nouvel states that small females spawn immediately after copulation, larger ones after $24 \mathrm{hr}$, but very large ones after $48 \mathrm{hr}$. Where copulation has not occurred the eggs fail to develop and drop off. This is apparently due to the very limited amount of secretion produced by the cement glands, the stimulus of copulation being apparently necessary possibly by way of the production of some hormone which affects these glands as suggested by Yonge (I937). In the anomuran, Diogenes pugilator, Bloch (I933) states that neither spawning nor moulting takes place without sexual stimulation.

Havinga (I929) considered that Crangon might copulate in brackish water and this is confirmed by observations in the Severn Estuary. In both 1937-8 and 1938-9, males disappeared from this region about the beginning of February (Fig. I4) and, although some females remained throughout the winter in $193^{8-9}$, in both years the appearance of egg-carrying females coincided with that of males. These females were all carrying newly-spawned eggs indicating that copulation must have occurred recently and therefore necessarily in the estuary when the salinity would lie between ro and $15 \%$.

Spawning and egg-carriage. The age at which sexual maturity is attained varies greatly with the locality. Havinga (1929) gives a minimum length of $43 \mathrm{~mm}$. in the Zuiderzee; Wollebaek (I908) of $36 \mathrm{~mm}$. in the colder waters off Norway; Meyer (1935a) found that some $50 \%$ of females between 35 and $40 \mathrm{~mm}$. long were carrying eggs during May in the Bay of Jade in Oldenburg. In the Bristol Channel the smallest egg-carrying females measured $45 \mathrm{~mm}$. and were taken in March and June (Fig. 9). But in the lower salinity of the estuary the minimum length was $47 \mathrm{~mm}$. and very few were less than $50 \mathrm{~mm}$. (Fig. IO).

As the time for spawning approaches, the animal refuses to eat and retires into a sheltered position. The pressure of the ovary on the stomach may prevent normal intake of food. Following moulting and copulation, the female cleans the egg-carrying setae by stroking movements with the tips of the second pair of pereiopods. During spawning the animal lies on one side with the abdomen bent under the thorax and the eggs then pass back in chains from the genital openings assisted by movements of the spoon-like endopodites of the first pair of pleopods. The 'raking' setae around the tips of these possibly assist by combing the eggs back. The second pair of pereiopods also help. H. \& L. Nouvel (I937) state that in other Caridea the pereiopods assist in the same way, but Höglund (r943), in his beautifully detailed account of spawning in Leander squilla, denies this. Here the female spawns while resting upright 


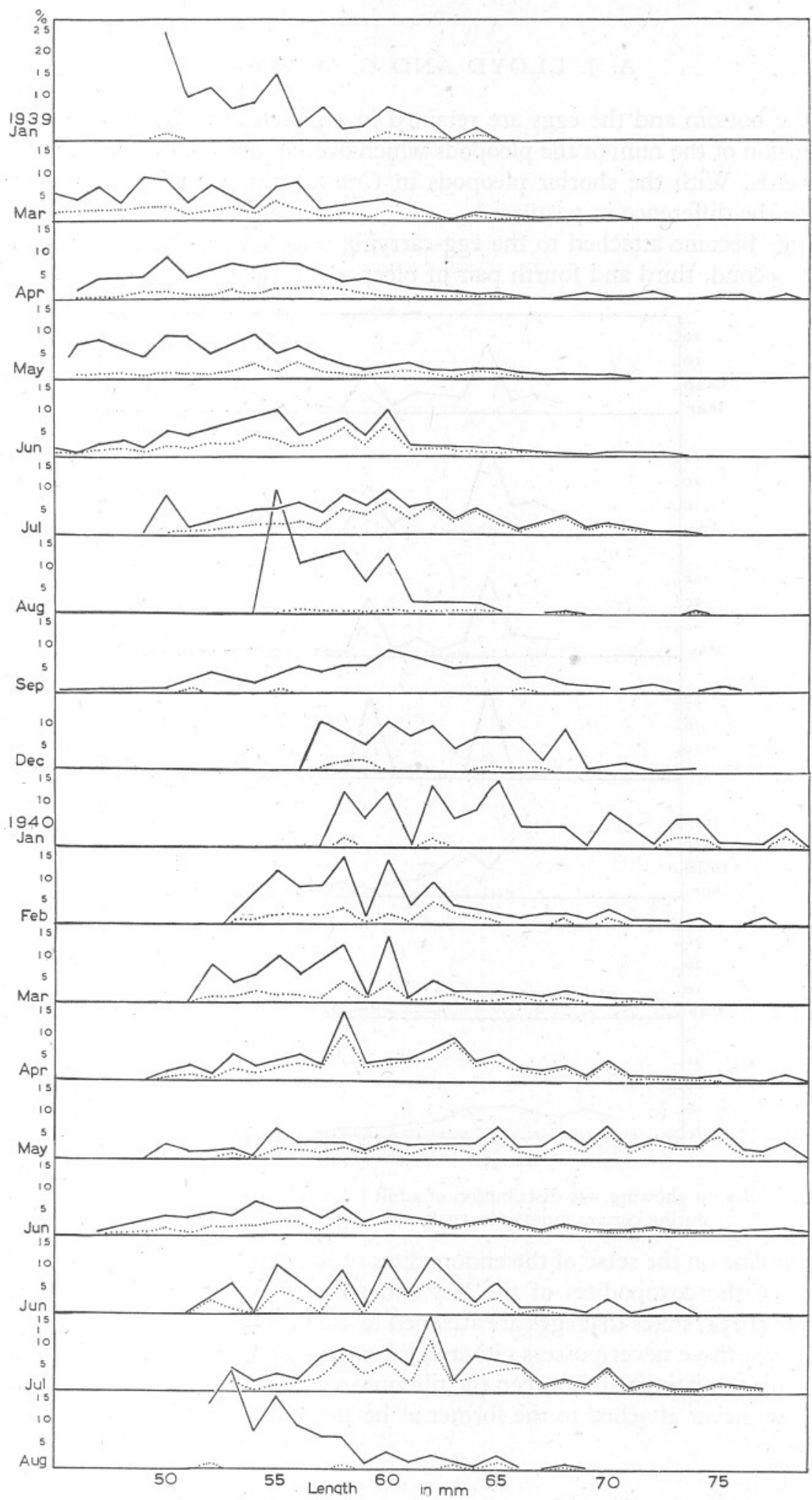

Fig. 9. Graphs showing size distribution in successive months of adult females in the Bristol Channel during I939 and I940. The continuous lines represent total female population above the minimum length for egg-carriage (i.e. adults), the dotted lines the percentage of egg-carrying individuals. 
on the bottom and the eggs are retained in a pouch formed by the forward extension of the rami of the pleopods which overlap one another from behind forwards. With the shorter pleopods in Crangon this would be impossible, hence the difference in posture.

Eggs become attached to the egg-carrying setae on the basipodites of the first, second, third and fourth pair of pleopods in the order given, then they

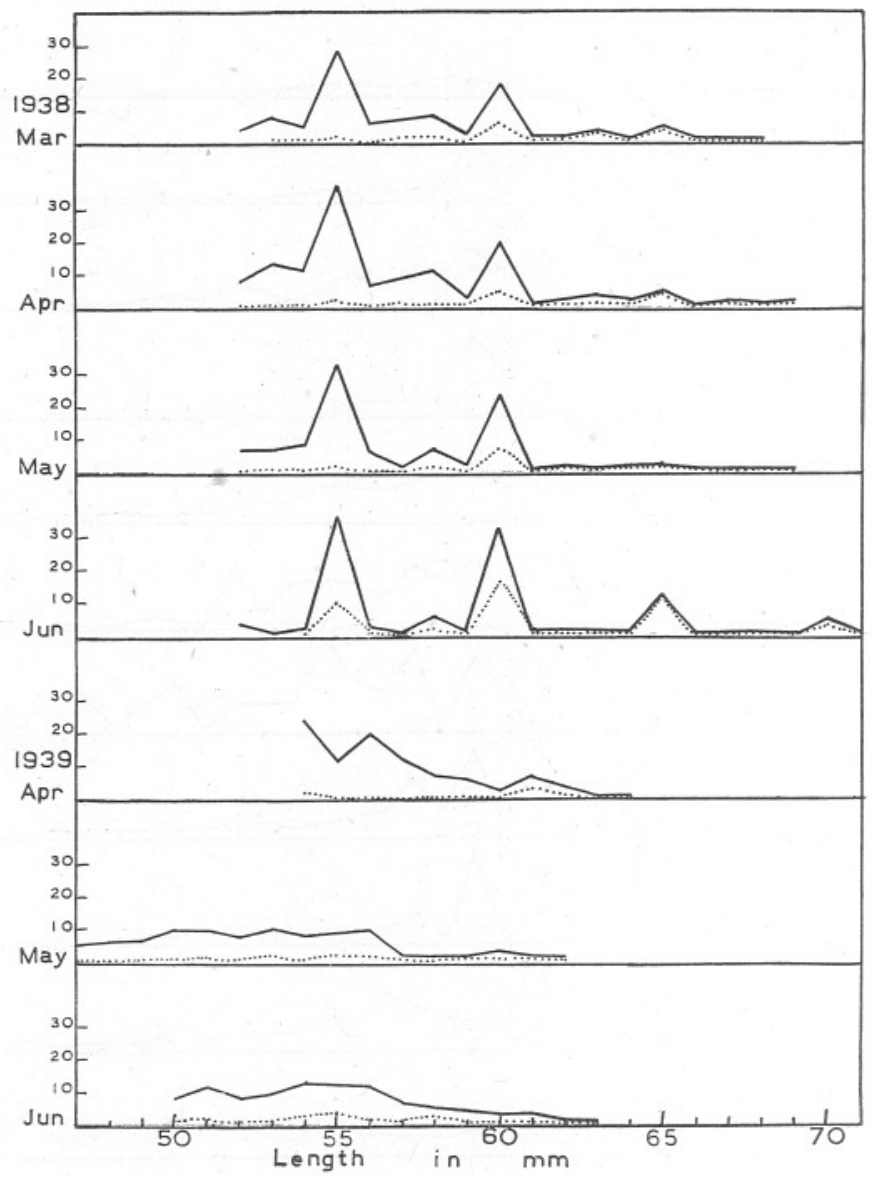

Fig. I0. Graphs showing size distribution of adult females in the Severn Estuary (Oldbury) during certain months in 1938 and 1939. Details as for Fig. 9.

accumulate on the setae of the endopodites of the first pair of pleopods and on those of the coxopodites of the last two pairs of pereiopods (see Fig. 5). Meyer (I934) states that eggs are attached to the fifth pair of pleopods, but this is not so; these never possess either egg-carrying setae or cement glands. $\mathrm{He}$ also fails to distinguish between the plumose setae and the egg-carrying setae; eggs are never attached to the former as he states. 
The egg mass is so attached that the exopodites with their fringing plumose setae are free to move and set up respiratory currents around the egg mass. There is a space between the ventral body wall and the eggs through which water can circulate. The eggs become firmly cemented to the setae in about $30 \mathrm{~min}$. This is in close agreement with Höglund's statement that in Leander squilla this process takes from a $\frac{1}{2}$ to $\mathrm{I} \mathrm{hr}$. He estimated that the actual process of egg extrusion only takes from 4 to $8 \mathrm{~min}$.

After the egg mass is securely attached, the animal swims vigorously but it does not feed so voraciously as during the preceding intermoult period when the demands of the ovary were so great. The pleopods frequently beat very actively and the female shows a marked preference for well aerated water.

The newly attached egg is spherical and from 0.35 to $0.4 \mathrm{~mm}$. in diameter. Later it enlarges, due to stretching of the outer, cuticular membrane (see Yonge, 1946), but almost exclusively in one diameter so that it becomes elliptical before hatching. At this time it becomes greenish-grey in colour and

Table II. One-day Samples of Adult Female Shrimps from Different Stations IN THE BRISTOL ChanNel SHOWING Condition OF THESE AND Restriction of 'Cemented' Individuals to the Months of ApriL AND MAY

\begin{tabular}{|c|c|c|c|c|c|c|}
\hline & & 1939 & & & I940 & \\
\hline & 'Neuter' & Cemented & Egg-carrying & 'Neuter' & Cemented & Egg-carrying \\
\hline January & - & - & - & 100 & 0 & 5 \\
\hline February & - & - & - & 352 & 0 & 33 \\
\hline March & 386 & o & 48 & 319 & o & 56 \\
\hline April & 259 & I5 & I7 8 & I05 & 72 & 68 \\
\hline May & 632 & 32 & I 84 & I $2 \mathrm{I}$ & 35 & I58 \\
\hline June & 739 & 0 & 523 & 204 & 0 & 210 \\
\hline July & 1220 & 0 & 380 & I46 & o & 84 \\
\hline August & 614 & o & 16 & 475 & 0 & 0 \\
\hline September & r 306 & 0 & 4 & 560 & 0 & 0 \\
\hline October & 249 & o & 0 & - & - & 一 \\
\hline November & 293 & 0 & I & - & - & - \\
\hline December & 317 & 0 & 8 & - & - & - \\
\hline
\end{tabular}

the eyes of the larvae are visible. Towards the end of the egg-carriage, Meyer (1935a) states that the egg mass is frequently probed and loosened by the second pereiopods which also assist in the final liberation of the larvae. This has been confirmed.

After hatching the egg membranes and strands of cement remain attached to the pleopods until the next moult. The period between hatching and moulting is longer in the spring than in the summer and for that reason 'cemented' shrimps were taken exclusively during April and May in the Bristol Channel (Table II). Analysis of collections made in April at Stolford and at Plymouth both show significant proportions of 'cemented' animals (Fig. II).

Spawning seasons. Ehrenbaum (I890), Havinga (1930) and Meyer (1935a) have all observed spawning Crangon in both summer and winter months along 


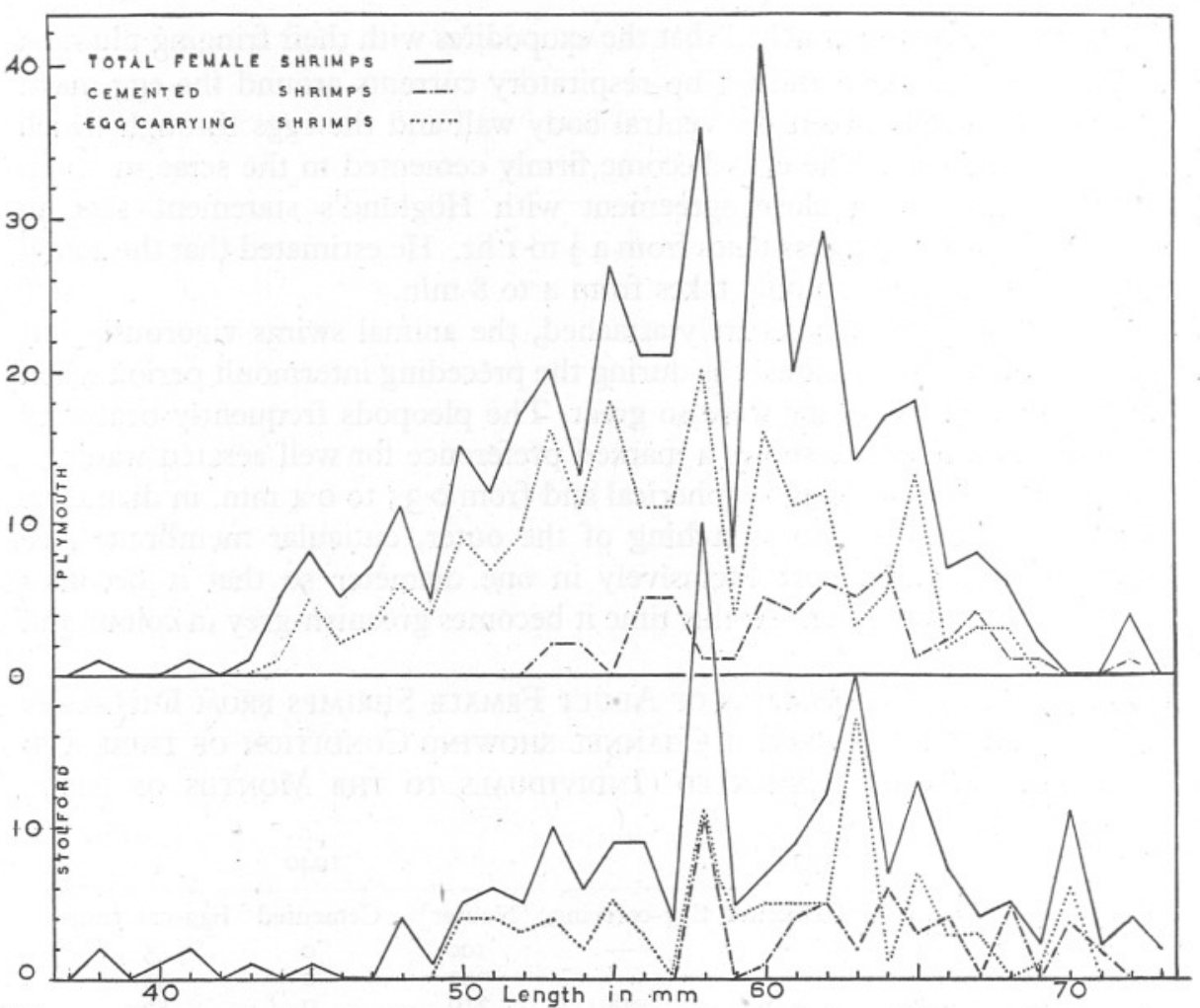

Fig. II. Graphs showing size distribution of total female population with proportion carrying eggs and proportion not moulted since the larvae were hatched (i.e. cemented). Graphs based on counts of samples obtained from Stolford and from Plymouth in April I940.

Table III. Percentage Egg-Carrying Crangon vulgaris in Relation to Temperature and Salinity throughout the Year in the Channel AND ESTUARY

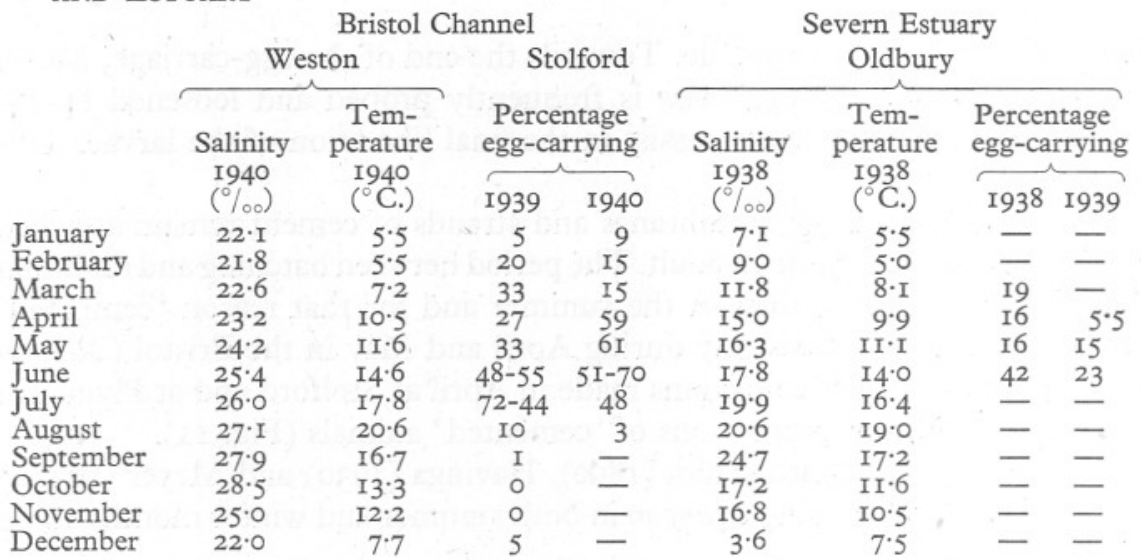


the continental shores of the North Sea. Ehrenbaum and Meyer, working at Caroliensiel and Jade Bay respectively, found two spawning periods, one extending from spring to the end of July and the other from November until February. Havinga, working in the Zuiderzee, found three spawning periods, in October, April and June.

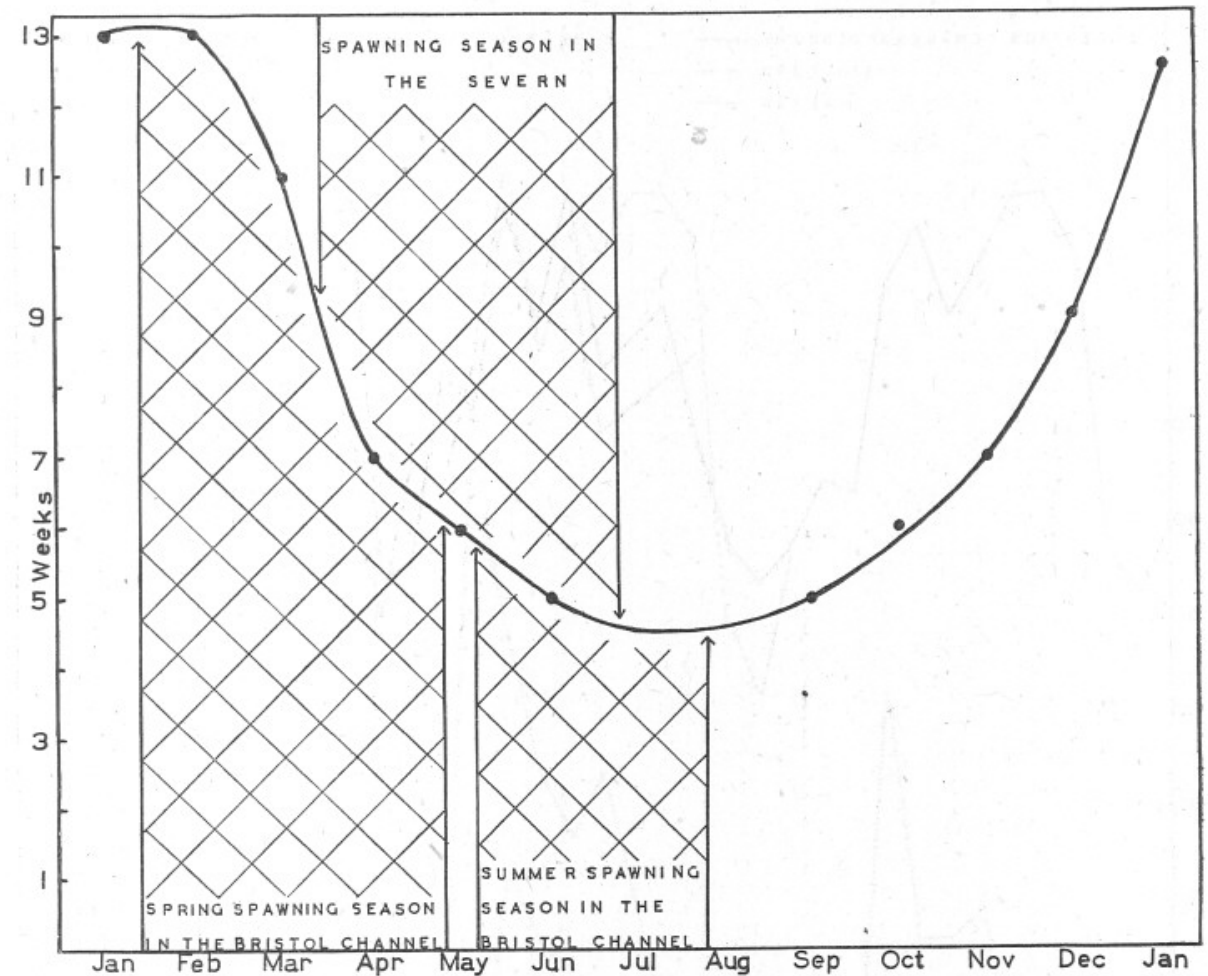

Fig. I2. Crangon vulgaris, diagram showing the spawning seasons in the Severn Estuary and the Bristol Channel and the probable duration in weeks of egg-carriage (based on data from Havinga, I930) at temperatures prevailing throughout the year.

In the Bristol Channel there are probably spring and summer spawning periods, although as shown in Table III and Fig. I3, the two overlap. The former starts at the end of January or in early February and lasts until midApril or the beginning of May (Fig. I2). The peak of this spawning was in March in 1939 (33\% of all females) and in April in 1940 (59\%), spawning being delayed in the latter year owing to the severe winter of 1939-40. Figures are given in Table III and displayed graphically in Fig. I3 (Stolford). Meyer (1935a) records greater numbers $(65-80 \%)$ of egg-carrying females during spring in Jade Bay. At the end of this spring spawning, in April or early May, large numbers of 'cemented' females were taken (Table II and Fig. II). At the 
temperatures prevailing in the Channel during the spring (Table III), the eggs were probably carried for some 7-10 weeks as indicated in Fig. I2. This figure was prepared using Havinga's data for the duration of egg development at various temperatures combined with personal observations on egg-carrying shrimps in the aquarium.

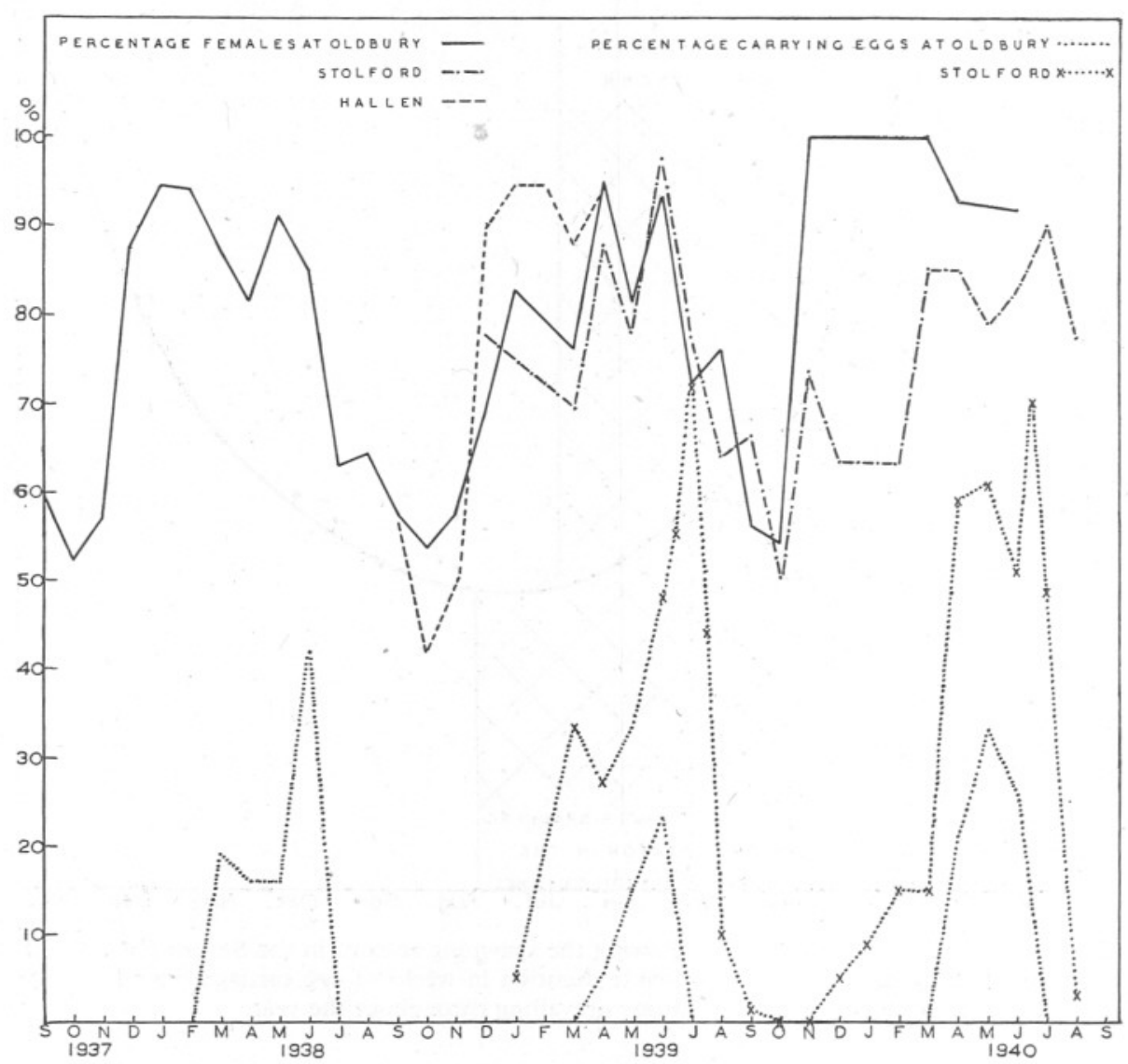

Fig. I3. Graphs showing percentages of total female and of egg-carrying individuals in the Severn Estuary (Oldbury, Hallen) and the Bristol Channel (Stolford) from I937 to I940.

Summer spawning in 1939 began in May and in 1940 during early June. Egg-carrying shrimps reached a maximum of $72 \%$ in July 1939 and at the end of June I940 (Table III; Fig. I3). Havinga records $95 \%$ females carrying eggs during these months. This second period of egg-carriage is largely over by the end of July although a few egg-carrying females were obtained in August and I \% in September 1939. But apart from these few there is a resting period from September to November. About $5 \%$ of the females taken at Stolford in December were carrying eggs but there was no general winter spawning like 
that recorded from the North Sea by Meyer (1935a) who found $69 \%$ of females carrying eggs from mid-October to mid-December and $40 \%$ up to mid-January. Thus at Stolford, as representative of conditions in the Bristol Channel, berried shrimps represent $5 \%$ and more of the total female population for nine months in the year, they are negligible in numbers during September and absent during October and November. In the zones of highest salinity in the Zuiderzee and Westerschelde, Havinga (1930) found that $50-60 \%$ of females were carrying eggs during eleven months of the year with a resting period either in January or February.

Unlike the Channel, egg-carrying shrimps occur in the Severn (at Hallen and Oldbury) only during the spring from March or April to June (Table III; Fig. I3). As already noted, there is good evidence that these animals copulate and spawn in these waters. The percentage of females carrying eggs reached a maximum of 42 and 23 in June 1938 and 1939 respectively. After June no spawning females were found until the following spring. Havinga (1930) obtained approximately $40 \%$ of berried shrimps from March-April until September-October in regions of low salinity comparable to those in the Severn Estuary.

The absence of winter spawning in the estuary is due to the lower salinities (minimum of $3.6 \%$ in December at Oldbury compared with $2 \mathrm{I} \cdot 8$ at Weston in February) which cause seaward migration of the males and, in some years, of the females also (see Fig. I4). Berried females do not appear until the return of the males when a salinity of approximately $12 \%$ prevails. The liberated larvae need a still higher salinity, hence the general tendency for seaward migration of berried animals prior to hatching.

\section{LIFE HISTORY}

The larvae of Crangon have been described by Ehrenbaum (I890), Havinga (I929) and Lebour (I93I). The length at hatching is $2 \mathrm{~mm}$. which increases to from 4.6 to $4.7 \mathrm{~mm}$. at the end of the fifth (last) larval stage when the animal leaves the plankton. Ehrenbaum thought that the planktonic period extends over some five weeks in the spring in the North Sea, but it is influenced by temperature. The variations in this $\left(5-2 \mathrm{I}^{\circ} \mathrm{C}\right.$.) during the ten months of the breeding season in the Bristol Channel must have a great effect on the length of time passed in the plankton. The length of the sixth (first post-larval) stage decreases to about $4.3 \mathrm{~mm}$., that of the seventh, eighth and ninth stages being $6,7.5$ and $10.5 \mathrm{~mm}$. respectively.

In the Bristol Channel quantities of Crangon around $6 \mathrm{~mm}$. long (i.e. second post-larval stage) were taken at Kilve, near Stolford, during May. They were presumably products of the spring spawning, while collections of shrimps ranging in the main between 15 and $25 \mathrm{~mm}$. in length taken at Stolford in June must have arisen from eggs carried in December and January (Table III). 
Meyer $\left(1935^{b}\right)$ found that larvae liberated in February attained a length of $22 \mathrm{~mm}$. by the end of July and of $3 \mathrm{I} \mathrm{mm}$. by the end of September in Jade Bay.

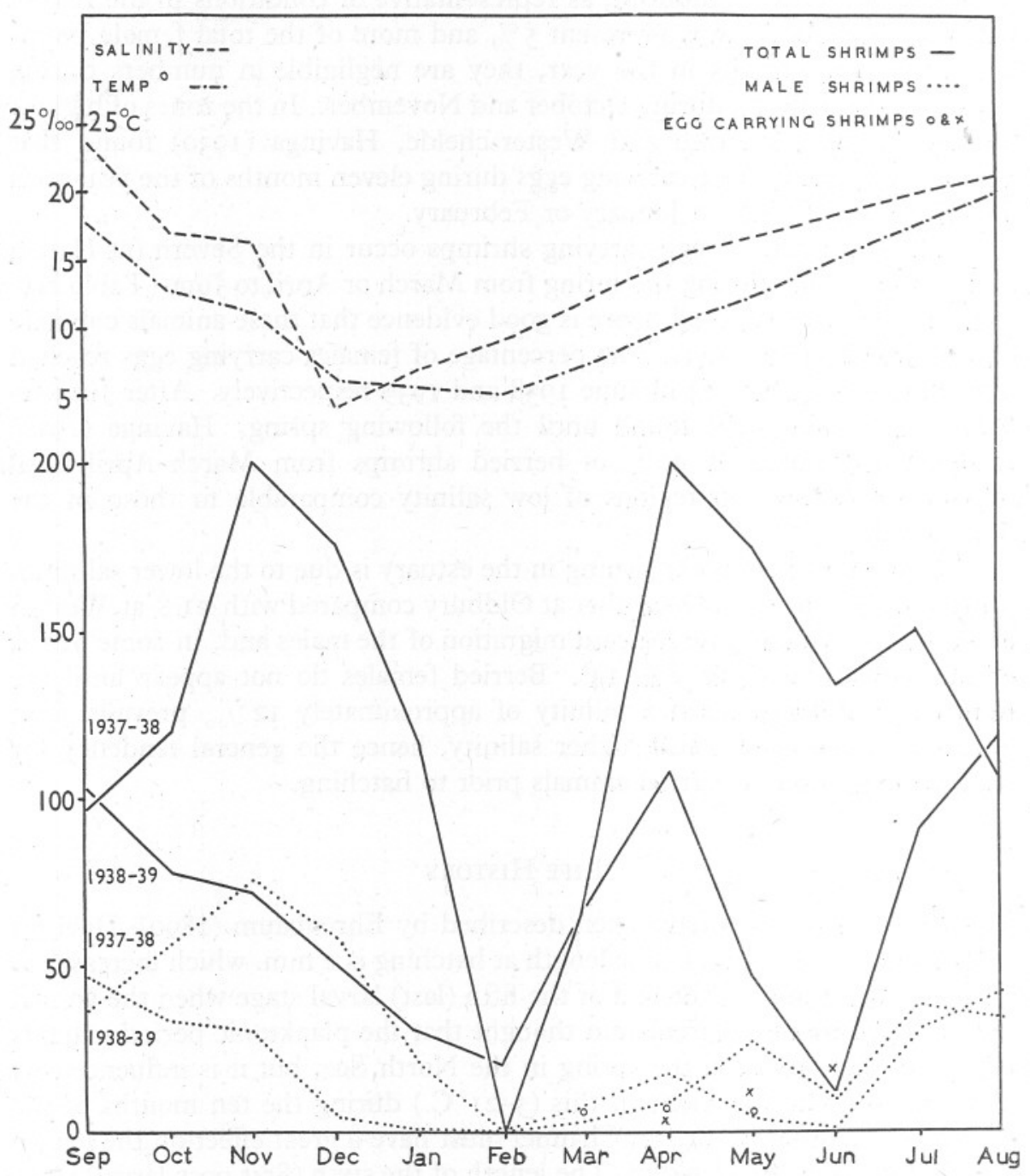

Fig. I4. Graphs based on bi-weekly counts of animals caught at Oldbury, showing fluctuations in numbers during 1937 to 1938 and 1938 to I939 both in the total population and in the male population in the Severn Estuary. Graphs for salinity and temperature are based on figures for 1938 to I939. Presence, and percentage, of egg-carrying females denoted by circles (I937-38) and crosses (1938-39).

This was followed by a further length increase of $7 \mathrm{~mm}$. over the following winter. But in the Bristol Channel these winter spawned animals are few 
compared with those produced during the spring and summer which constitute the main size groups during each month although random migrations frequently make it impossible to distinguish the different classes. In the estuary, shrimps IO-I $5 \mathrm{~mm}$. long were taken at Shepardine in July. They may have been the products of animals spawning in March.

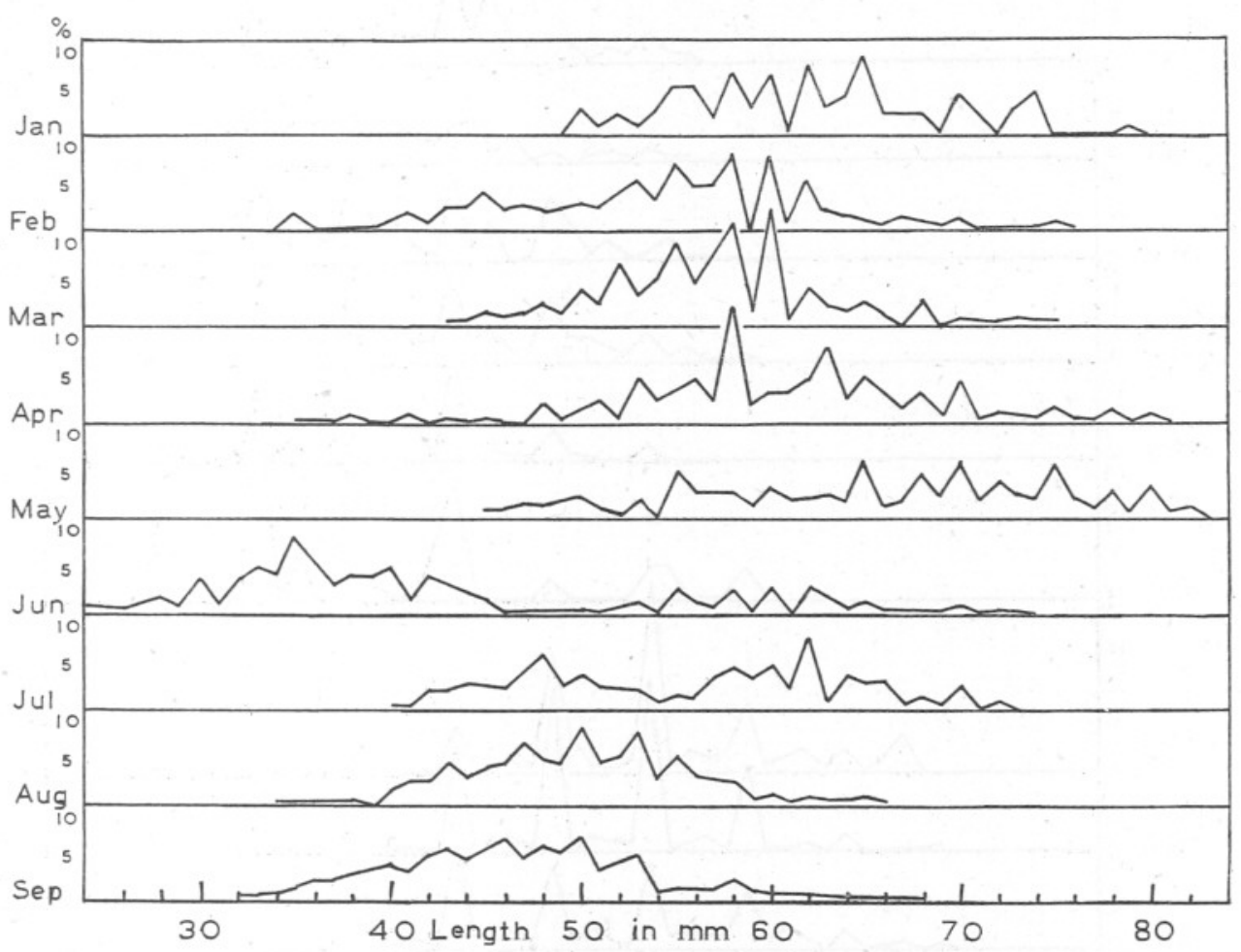

Fig. 15. Graphs showing size distribution in successive months of females collected from the Bristol Channel from Jan. to Sept. I940.

The young shrimps move offshore in the autumn and do not reappear until the following summer when in June 1939 and June 1940 (Fig. I5), animals spawned the previous spring and summer appeared in the Channel at lengths of between 25 and $45 \mathrm{~mm}$. Havinga (I930) gives the length at the end of one year as $35 \mathrm{~mm}$.; Meyer (1935b) estimates it as about $37-38 \mathrm{~mm}$. But it is difficult to be precise when the spawning period is so long.

During the first year of life the growth rate of the two sexes appears to be very similar. Subsequently the females grow more rapidly although, owing to the frequent periods of egg-carriage when growth is arrested and the cessation of growth during the winter, all workers agree on the difficulty of interpreting growth data. In the North Pacific species, Crago (Crangon) 
franciscorum and C. nigricauda, Israel (I936) found that a differential growth rate sets in at an early age, the females growing more rapidly and becoming $25 \%$ larger than the males.

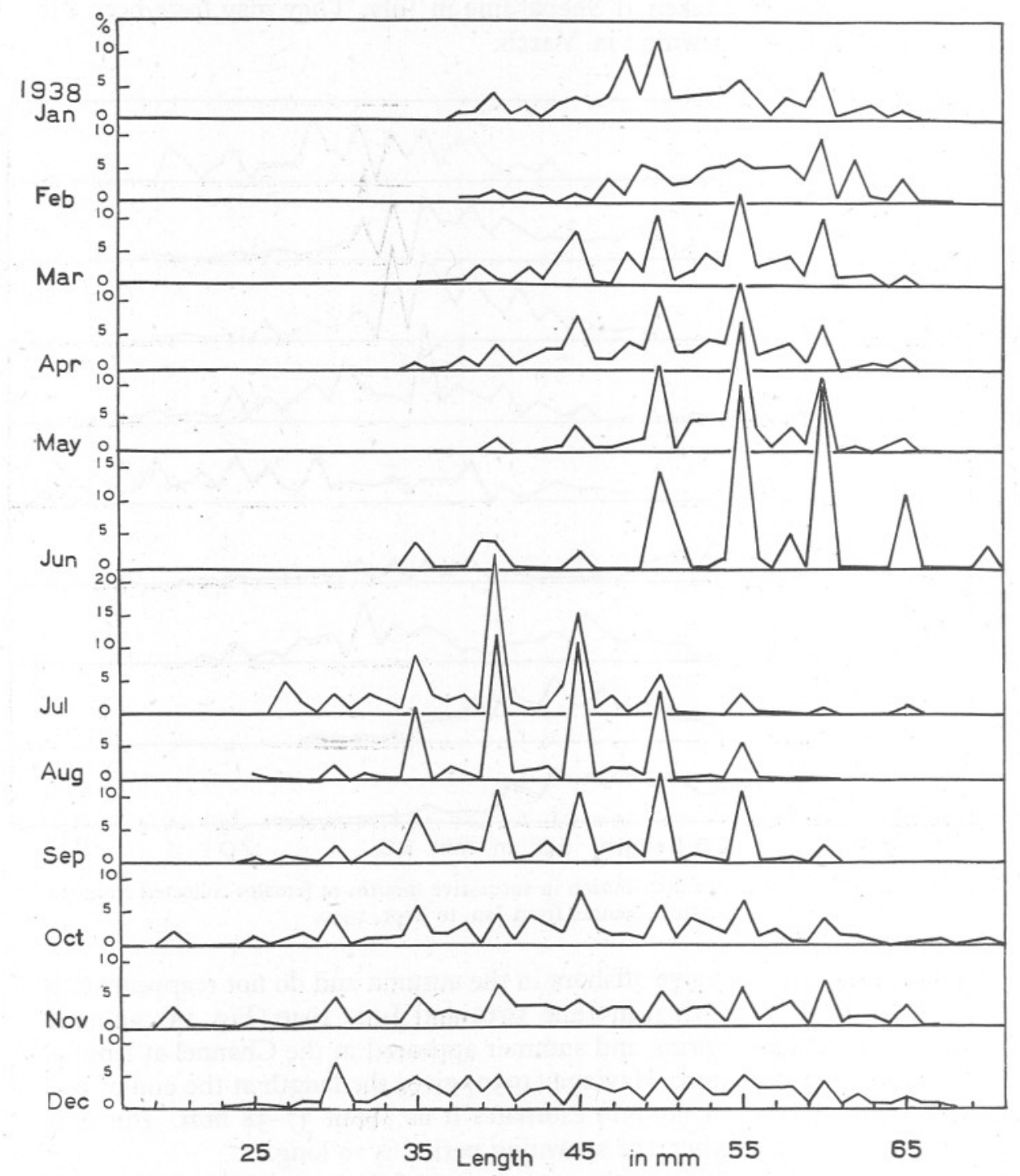

Fig. I6. Graphs showing size distribution in successive months of females collected from the Severn Estuary from Jan. to Dec. I938.

As shown in Fig. 15, young females which enter the population in the Channel in June add some Io $\mathrm{mm}$. to their length in the following month, presumably as a result of two 'neuter' moults. They are then largely between $45-55 \mathrm{~mm}$. long 
and so capable of moulting into the egg-carrying condition and spawning. The arrest of growth due to this is indicated by the general similarity of the graphs for length during July, August and September. In the Severn (Fig. I6), a similar female population, up to $45 \mathrm{~mm}$. long, appears in July after the older females present throughout the first part of the year have spawned and then migrated seaward. As shown in Fig. I3 and Table III, breeding is completed in June in the Severn (Oldbury) and indeed only a small section of this first year population reaches the minimum size for spawning ( $50 \mathrm{~mm}$., see p. 642) in these estuarine waters.

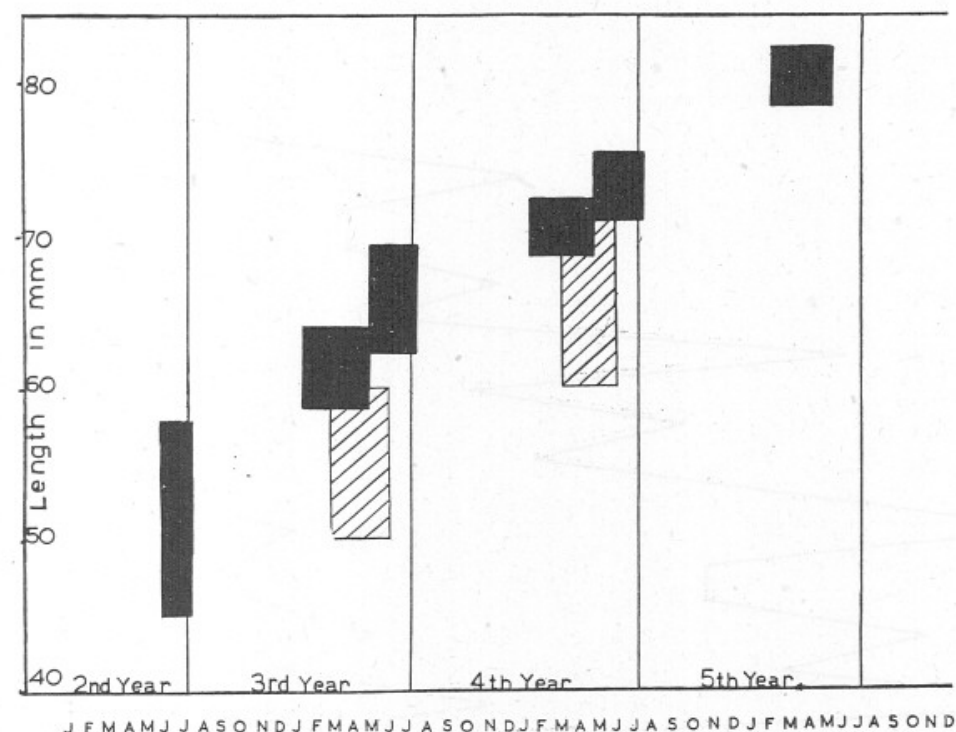

Fig. 17. Diagrams showing length of spawning females and the spawning periods in the Bristol Channel (shown black) and in the Severn Estuary (shown shaded).

The evidence would thus seem to indicate that spawning begins in the Channel about the beginning of the second year of life when the females are mainly between $45-55 \mathrm{~mm}$. long but that in the Severn not until a year later. As shown in Fig. I7, there is probably only one breeding period in the Channel in the second year but there are two such periods in both the third and fourth years at lengths of about $60-70 \mathrm{~mm}$. and of up to $75 \mathrm{~mm}$. respectively. A few females survive the fourth winter to reappear at lengths of about $80 \mathrm{~mm}$. in the fifth year, as in May, 1940 (Fig. I5). In the Severn there is only one spawning period annually (Fig. I7), the great bulk of the breeding animals being in their third year, at lengths of between 50 and $60 \mathrm{~mm}$., and a few in their fourth year when over $60 \mathrm{~mm}$. as shown in Figs. I0 and I6.

After sexual maturity has been attained, at a length of about $50 \mathrm{~mm}$., mortality must be high, as indicated in Fig. 18. Only 25 out of some 


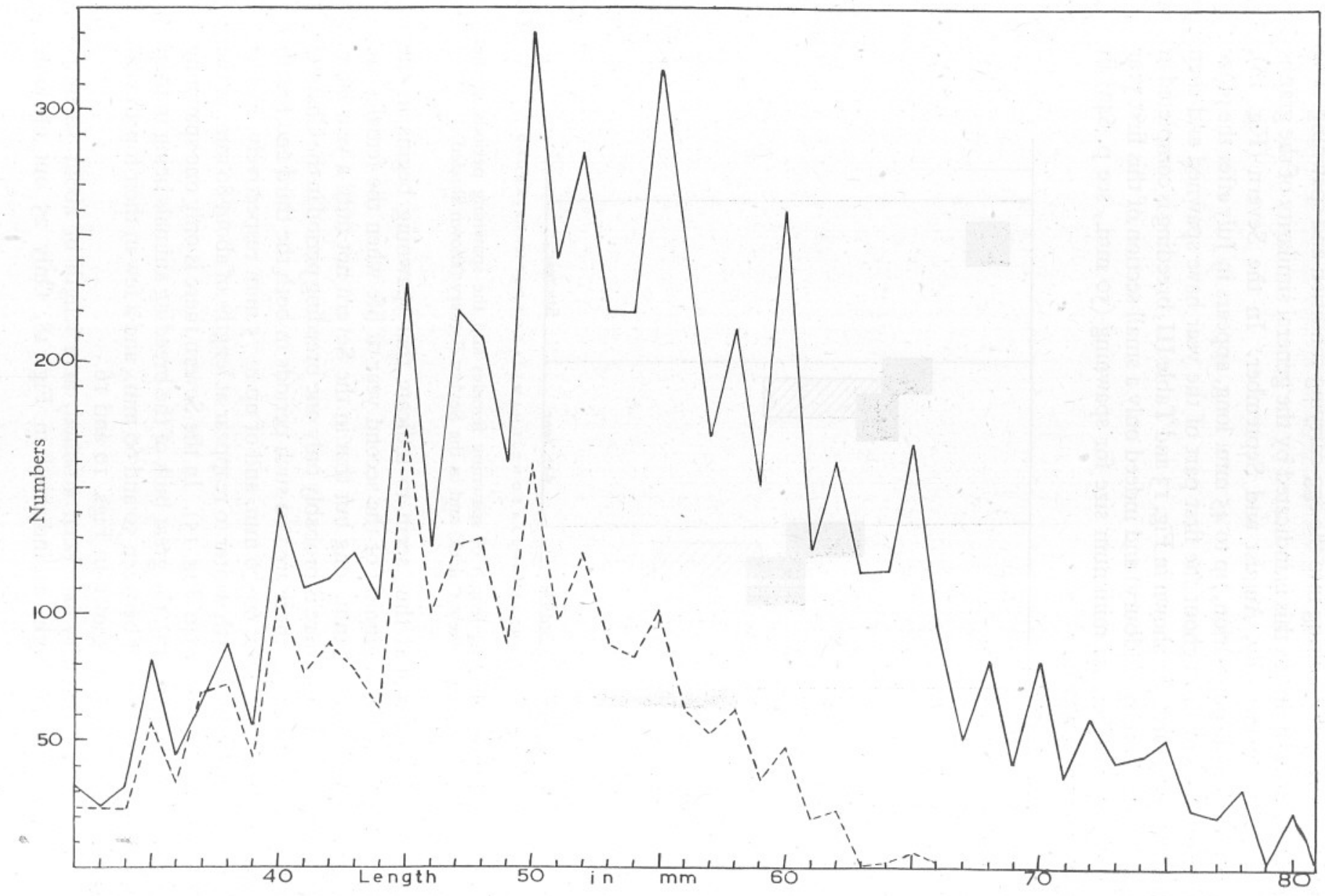

Fig. 18. Graph showing size distribution of all females (continuous line) and males (broken line) collected from the Bristol Channel during 1939. 
22,000 females measured exceeded $80 \mathrm{~mm}$. in length although Havinga obtained occasional specimens as long as $9 \mathrm{I} \mathrm{mm}$.

It is difficult to be certain about the growth rate of the males because of the smaller numbers taken; the reasons for this are discussed later. Young males appeared in the Channel at lengths of under $40 \mathrm{~mm}$. in July and December 1939 (Fig. I9) and under $35 \mathrm{~mm}$. during June and July 1938 in the Severn (Fig. 20).

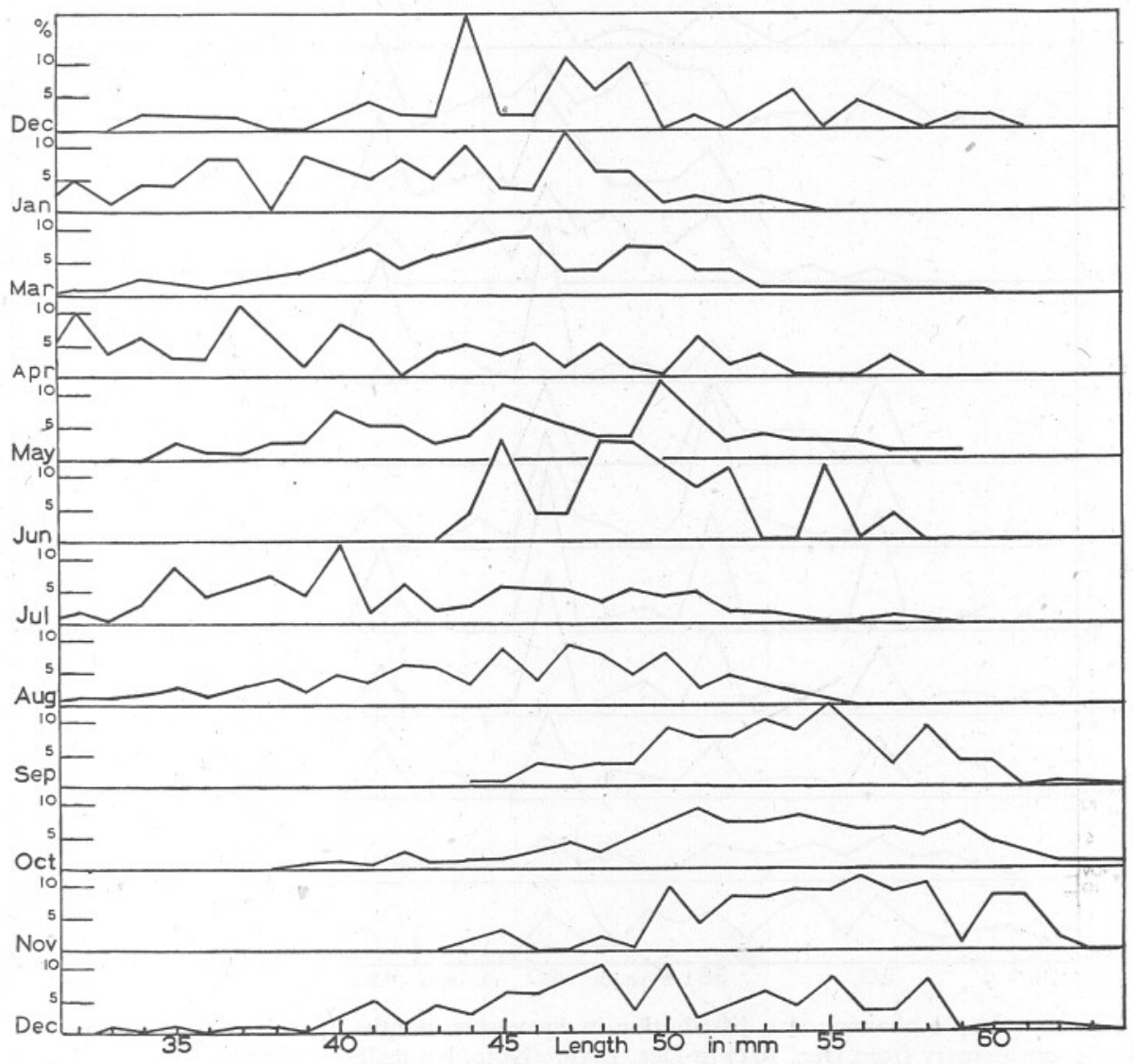

Fig. 19. Graphs showing size distribution in successive months of males collected from the Bristol Channel from Dec. 1938 to Dec. 1939.

Probably males do not enter these estuarine waters until the end of the first year of life and then quickly become mature. Comparison of the size groups of the two sexes in the Severn from July to September (Figs. I6 and 20) reveals that the males are smaller. The spring population in the estuary appears to consist of second-year males with maximum numbers between 40 and $45 \mathrm{~mm}$. long (Fig. 20) together with third-year females largely, between 50 and $60 \mathrm{~mm}$. 
long (Fig. I6). During the summer an extreme length of $55 \mathrm{~mm}$. is attained by some males but animals of this size are rare, the death-rate being high after lengths of $50 \mathrm{~mm}$. are reached as shown in Fig. I8. Two males $70 \mathrm{~mm}$. long were taken in the summer and these may have been four years old.

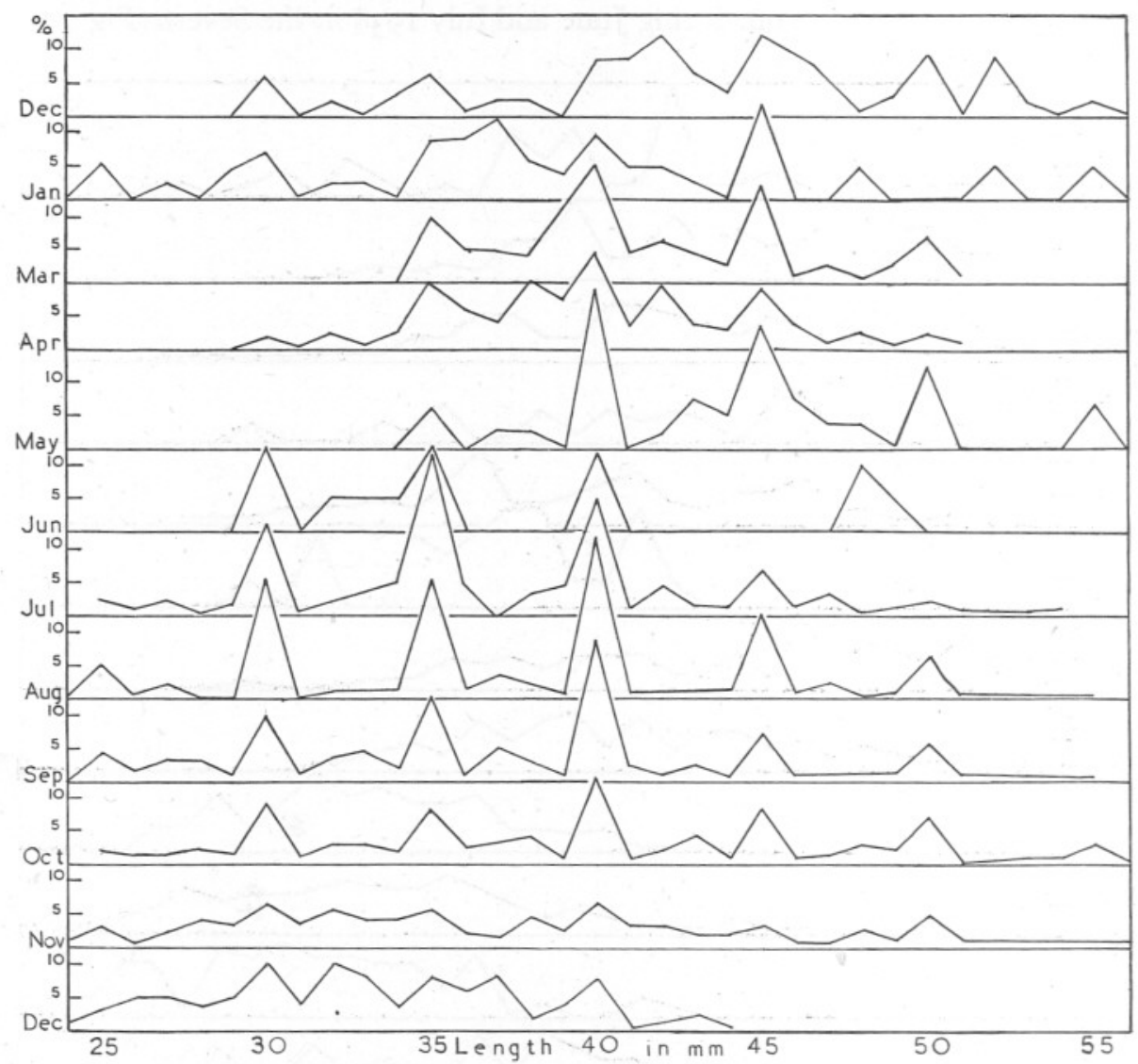

Fig. 20. Graphs showing size distribution in successive months of males collected from the Severn Estuary from Dec. I937 to Dec. 1938. (Note. No males were found in February.)

\section{MigRATIONS}

Ehrenbaum (I890), Havinga (1930) and Meyer (1935b) all recorded an offshore migration of Crangon to deeper waters in the North Sea during the winter and an inshore migration in the spring. Israel (1936) reports similar movements of C. franciscorum and C. nigricauda in the Pacific. Similar migrations, as already stated, occur in the Bristol Channel and Severn Estuary. These migrations are clearly related to salinity and temperature. 
Data for the Severn were obtained primarily at Oldbury (Fig. I, station 2), for the Channel at Weston (station 4). Low water salinities were lowest at Oldbury in December (Table III; Fig. I4) and though salinity rose from $3.6 \%$ in that month to $9.0 \%$ in February in the salmon pool where the shrimps were caught, observations in mid-channel indicated that the salinity there was lowest in February. This is certainly true at Weston (Table III), although figures are much higher, namely $2 \mathrm{I} \cdot 8 \%$. During the spring and summer, salinities rise, reaching a maximum of $24.7 \%$ in September at Oldbury and of $28.5 \%$ in October at Weston. There is little difference between the temperatures in the two regions; in both the lowest figures are in February $\left(5.0\right.$ and $5.5^{\circ} \mathrm{C}$.) and highest in August (I9 and $20.6^{\circ} \mathrm{C}$.).

During February few (1939), or no (1938), Crangon were taken at Oldbury (Fig. I4) but, beginning in March, there was an extensive migration into the estuary. The females, in the main 50-55 mm. long, were much more numerous than the males (Fig. I4). Only a few females carried eggs. The migration reached its maximum in April after which numbers declined because many females left the Severn to liberate the larvae in more saline waters. This movement was reflected in an increase of approximately $70 \%$ in the numbers taken at Stolford (station 6) during early July.

During June and July the estuary was restocked by the appearance of females up to $45 \mathrm{~mm}$. long (Fig. I6) and males up to $35 \mathrm{~mm}$. long (Fig. 20). This migration reached maximum dimensions early in November in 1937 but sooner in I938 (Fig. I4). A seaward migration followed and this continued during the winter. Males were completely absent in February in both 1938 and 1939 and females also in 1938. This winter migration is closely associated with the declining temperature and salinity as shown in Fig. I4. On the other hand shrimps are never completely absent from the Channel where similar temperatures but higher salinities prevail (see above). It is thus apparently the low salinity of the estuary which is the prime factor causing seaward migration. Similar migrations occur, although to a smaller extent, in the Channel but are most marked near the mouths of rivers flowing into the Channel, for instance at Burnham (station 5).

There was little difference between the percentages of females at each station during any month (Fig. I3) and any fluctuations were shown simultaneously at Oldbury, Hallen and Stolford. Thus the movements of Crangon take place in a regular manner throughout the area being apparently influenced by alterations in environmental factors equally at each station.

The percentage of males taken at these three stations was 36 at Oldbury, 30 for Hallen and 27 for Stolford. The higher figure at Oldbury is probably due to the use there of a stramin net round the end of the putt which caught smaller animals than was possible at the other stations. But even this figure represents a low ratio of males. A number of factors are probably responsible for this. First, the males live for a shorter time than the females. Second, they 
are unable to withstand the low salinity, combined with low temperature, in the winter. The greatest influx of males at each station occurred during September to October when they may constitute $40-50 \%$ of the population as shown in Table IV.

This Table also includes Havinga's data for the Zuiderzee and Westerschelde, where high salinities are about $26 \%$ and low salinities from 5 to $10 \%$, i.e. comparable in many respects with those in the Channel and Severn respectively. The percentages of males obtained in the Channel are in the main not unlike those obtained in the most saline zones of the Westerschelde, but the brackish waters of the Severn appear to have a larger population of males than those of similar waters in the North Sea where the males only appear between July and October. Possibly higher temperatures in the Severn may explain the presence of males over the greater part of the year.

Table IV. Percentage of Male CRAngon Vulgaris throughout the Year In Zones of Highest (H.S.Z.) and Lowest Salinity (L.S.Z.) IN Dutch Waters (From Havinga, I930) AND In the Bristol Channel and SEVERN ESTUARY DURING I939

\begin{tabular}{|c|c|c|c|c|c|c|}
\hline & \multicolumn{6}{|c|}{ Percentage male shrimps } \\
\hline & \multirow{2}{*}{\multicolumn{2}{|c|}{ Zuiderzee }} & \multirow{2}{*}{\multicolumn{2}{|c|}{ Westerschelde }} & \multicolumn{2}{|c|}{$\begin{array}{l}\text { Bristol Channel and } \\
\text { Severn Estuary }\end{array}$} \\
\hline & & & & & Stolford & Oldbury \\
\hline & H.S.Z. & L.S.Z. & H.S.Z. & L.S.Z. & H.S.Z. & L.S.Z. \\
\hline January & $5 \mathrm{I}$ & - & - & - & 25 & I8 \\
\hline February & - & - & 45 & - & - & 0 \\
\hline March & 47 & - & $3 I$ & 0 & $3 I$ & I4 \\
\hline April & 50 & 0 & 29 & 0. & 12.5 & 5 \\
\hline May. & I9 & 0 & 23 & 0 & 22 & I9.5 \\
\hline June & I4 & 0 & 27 & 0 & 2.5 & 7 \\
\hline July & 66 & 49 & 24 & - & 23 & 38 \\
\hline August & 78 & - & 39 & 43 & 36 & 34 \\
\hline September & 68 & 27 & 29 & $6 I$ & $34 \cdot 5$ & 44 \\
\hline October & 53 & I3 & 25 & - & 50 & 46 \\
\hline November & & - & 48 & - & 26 & 0 \\
\hline December & 56 & - & 53 & - & 36 & 0 \\
\hline
\end{tabular}

(Note. The graph in Fig. I4 does not cover the last four months of I939.)

Although both sexes are unable to withstand low salinity when combined with low temperature, the field observations here recorded, confirming those of earlier workers, combined with the results of the experiments on the effect of varying salinity on respiration in the two sexes, reveal clearly the greater susceptibility of the males. There is apparently a well-marked physiological distinction between the sexes in respect of osmo-regulation which may be the result of fundamental metabolic differences. As already recorded, females can withstand exposure to freshwater for considerable periods and it may be that an annual invasion of freshwaters is prevented by the inability of the males to withstand such conditions. That dependence of the larvae on saline conditions is no such bar to freshwater life by the adults is shown in Eriocheir. 


\section{SUMMARY}

Collections of some 22,000 female and 6000 male Crangon vulgaris were made throughout the year from the shrimp fisheries of the Severn Estuary and Bristol Channel. All animals were measured.

The habits of the species are described; it can withstand a wide range of temperature but, though euryhaline, resembles other Decapoda in the inability to withstand low salinity combined with low temperature.

Osmo-regulation is apparently largely inhibited at low temperatures and to a greater extent in the males than the females.

Growth rate decreases with increasing age; in the female there is no increase in length when moulting from the 'neuter' to the egg-carrying intermoult.

The duration of this intermoult, if spawning is successful, is about double that of the normal intermoult under the same temperature conditions.

Growth almost ceases in the winter.

Secondary sexual characters are described, especially the differences between the endopodites of the pleopods in the two sexes.

Females become mature at a minimum length of $45 \mathrm{~mm}$. in the Channel and seldom less than $50 \mathrm{~mm}$. in the Estuary. The effect of the female sexual cycle on the size of the ovary and the form of the pleopods is described.

The process of copulation is described; it can occur in the brackish waters of the estuary. Egg-laying always follows within two days of moulting into the egg-carrying condition but eggs are not retained if copulation has not occurred.

The females lie on their sides during the act of spawning and the eggs are firmly attached within thirty minutes to the egg-carrying setae on the basipodites of the first to fourth pair of pleopods, then to those on the endopodite of the first pleopod, finally to those on the coxopodites of the last two pairs of pereiopods.

The period of egg-carriage varies from about four weeks in mid-summer to thirteen weeks in the winter.

There are probably two overlapping periods of spawning in the Channel, in spring and summer, and only one, starting somewhat later in the spring, in the estuary.

The adult life history is deduced from measurements taken throughout the year. During the first year the growth rate is similar in the two sexes but subsequently the females grow more rapidly. Females live longer and attain a maximum size of over $80 \mathrm{~mm}$., the two largest males taken being $70 \mathrm{~mm}$. In the Channel the females probably spawn once in the second year of life, twice in the third and fourth years, while a few may survive to spawn in the fifth year. In the estuary spawning is apparently confined to the third and fourth years.

There is a pronounced migration in winter from all stations but especially from the less saline estuarine areas where males were absent in the coldest months and, in one year, females also. In the spring the females return to the 
estuary before the males but migrate seaward again after spawning, the estuary being restocked during July by animals spawned the previous year. Except during September and October the males are always much less numerous than the females at all stations.

Complete penetration of fresh waters by Crangon vulgaris is possibly prevented by the great susceptibility of the males to low salinity.

\section{REFERENCES}

BaLss, H., I930. Wanderungen bei Decapoden (Crustaceen). Erg. de Biol., Bd. 6, pp. 305-26.

BLoch, F., I933. Fécondation et maturation de l'œuf chez un Pagure, Diogenes pugilator Roux. C.R. Acad. Sci., Paris, T. 196, pp. 429-31.

BRoekema, M. M. M., I94I. Seasonal movements and the osmotic behaviour of the shrimp Crangon crangon. Acad. Thesis, Groningen, roo pp.

Broekhuysen, G. J., I936. On development, growth and distribution of Carcinides maenas (L.). Arch. néerl. Zool., T. 2, 257-399.

CAUdri, L. W. D., I937. Einfluss der Temperatur und des Salzehalts auf die Sterblichkeit von Garnelen (Crangon crangon L.). Arch. néerl. Zool., T. 3, I79-96.

Ehrenbaum, E., I890. Zur Naturgeschichte von Crangon vulgaris Fabr. Mitt. sekt. Küsten- $u$. Hochseefisch., Jahrg. I890, I24 pp.

GrobBen, C., I878. Beiträge zur Kenntniss der männlichen Geschlechtsorgane der Dekapoden, nebst vergleichenden Bemerkungen uber die der übrigen Thoracostaken. Arb. zool. Inst. Wien, Bd. I, pp. 57-150.

Havinga, B., 1929. Krebse und Weichtiere. Handb. Seefisch. Nordeuropas, Bd. 3, pp. $53-87$.

- 1930. Der Granat (Crangon vulgaris Fabr.) in den Holländischen Gewässern. 7. Con. Inter. Exp. Mer, Vol. 5, pp. 57-87.

HeRRICK, F. H., I894. The reproduction of the lobster. Zoologist, Vol. I8, pp. 4I3-I7.

- I9II. Natural history of the American lobster. Bull. U.S. Bur. Fish., Vol. 29, pp. I49-408.

HöGLUND, H., I943. On the biology and larval development of Leander squilla (L.) forma typica de Man. Sven. Hydro.-Biol. Komm. Skr., Ny Ser., Biol., Vol. II, Nr. 6 ,

ISRAEL, H. R., 1936. A contribution toward the life histories of the Californian shrimps, Crago franciscorum (Stimpson) and Crago nigricauda (Stimpson). Div. Fish Game California, Bur. Com. Fish., Fish Bull., No. 46.

Lebour, M. V., I93I. The larvae of Plymouth Caridea. I. The larvae of Crangonidae. Proc. Zool. Soc. Lond., I93I, (I), pp. I-9.

Lloyd, A. J. \& Yonge, C. M., I940. Correlation between egg-carrying setae and cement glands in Decapod Crustacea. Nature, Vol. I46, p. 334.

Mathias, P., I938. Sur la résistance de Palaemon squilla $\mathrm{L}$. et de Crangon vulgare F. à la diminution de salure de l'eau. Bull. Soc. zool. France, T. 63, 337-43.

Matthews, L. H., I933. The sea fish and fisheries of the Bristol Channel. Proc. Bristol Nat. Soc., (4), Vol. viI, pp. 442-62.

MeYer, P. F., 1934. Ein Beiträge zur Eiablage der Nordseekrabbe (Granat) Crangon vulgaris Fabr. Zool. Anz., Bd. I06, pp. 145-57.

- 1935a. Ein Beiträge zur Frage der Laichperiodizität bei der Nordseekrabbe (Granat) Crangon vulgaris Fabr. Zool. Anz., Bd. I09, pp. 23-32. 
MeYeR, P. F., 1935b. Wachstums- und Altersuntersuchungen an der Nordseekrabbe (Granat) Crangon vulgaris Fabr. Zool. Anz., Bd. I I , pp. 145-52.

Mouchet, S., I93I. Sur l'appareil génital mâle de Peneus trisulcatus Leach. Bull. Soc. zool. France, T. 6I, pp. 458-67.

Nouvel, H. \& Nouvel, L., I935. Observations sur la biologie d'une crevette: Athanas nitescens Leach. Bull. Inst. Ocean. Monaco, No. 685.

- I937. Recherches sur l'accouplement et la ponte chez les Crustacés Décapodes Natantia. Bull. Soc. zool. France, T. 62, pp. 208-2I.

Nouvel, L., I939. Observation de l'accouplement chez une espèce de crevette Crangon crangon. C.R. Acad. Sci., Paris, T. 209, pp. 639-4I.

Nouvel-VAN RYSSELberge, L., I937. Contribution à l'étude de la mue, de la croissance et de la régénération chez les Crustacés Natantia. Rec. Inst. zool. Torley-Rousseau, T. 6, pp. 9-16I.

Отто, J. P., I934. Úber den osmotischen Druck der Blutflüssigkeit von Heteropanope tridentata (Mainland). Zool. Anz., Bd. I08, pp. 130-5.

- I937. Úber den Einfluss der Temperatur auf den osmotischen Wert der Blutflüssigkeit bei der Wollhandkrabbe. Zool. Anz., Bd. I19, pp. 98-105.

PANIKKar, N. K., I940. Influence of temperature on osmotic behaviour of some Crustacea and its bearing on problems of animal distribution. Nature, Vol. I46, p. 366.

- I94I. Osmo-regulation in some palaemonid prawns. Fourn. Mar. Biol. Assoc., Vol. 25, pp. 317-59.

Plankemann, H., I935. Beiträge zur Physiologie der-Garneelenhäutung. Schr. naturw. ver. Sch.-Holst., Bd. 21, pp. I95-2I6.

Sollaud, E., I922. Recherches sur l'embryogénie des Crustacés Décapodes de la sous-famille des 'Palemoninae'. Bull. Biol. France Belg., Suppl. 5, pp. I-234.

SPALDING, J. F., I942. The nature and formation of the spermatophore and sperm plug in Carcinus maenas. Quart. F. Micr. Sci., Vol. 83, pp. 399-422.

Vitzou, A. N., I882. Recherches sur la structure et la formation des téguments chez les Crustacés Décapodes. Arch. Zool. exp. gen., Bd. Io, pp. 45I-577.

Wollebaek, A., I908. Remarks on Decapod Crustaceans of the North Atlantic and the Norwegian Fjords (I and II). Bergens Mus. Aarb., I908, Nr. I2.

YoNGE, C. M., I937. The nature and significance of the membranes surrounding the developing eggs of Homarus vulgaris and other Decapoda. Proc. Zool. Soc. Lond., A., Vol. I07, pp. 449-5 I7.

- I946. Permeability and properties of the membranes surrounding the developing egg of Homarus vulgaris. Fourn. Mar. Biol. Assoc., Vol. 26, pp. 432-8. 